\title{
Nexus between Human Values and Overall Satisfaction with the Urban Environment. A Non-Lineal Partial Least Square Path Modeling. Argentine Cities Case
}

\author{
Hector Oscar Nigro \\ Computer Science and Systems Department. Universidad Nacional del Centro de la \\ Provincia de Buenos Aires. \\ Paraje Arroyo seco s/n., Campus universitario, Tandil, Argentina. \\ E-mail: oscarnigro@speedy.com.ar \\ Sandra Elizabeth Gonzalez Císaro (Corresponding author) \\ Computer Science and Systems Department. Universidad Nacional del Centro de la \\ Provincia de Buenos Aires. \\ Paraje Arroyo seco s/n., Campus universitario, Tandil, Argentina. \\ E-mail: sagonci@exa.unicen.edu.ar or sagonci@gmail.com
}

Received: March 13, 2017 Accepted: April 16, 2017 Published: April 19, 2017

doi: 10.5296/jsss.v4i2.10934 URL: http://doi.org/10.5296/jsss.v4i2.10934

\begin{abstract}
In this paper, we examine the relationship between Human Values and the Urban Environment, and how values are behaviorally instantiated in different environments, through Non-Linear Structural Equation Model based on Partial Least Square. Beginning with a unified framework of the study of values, we analyze its organization, antecedents, covariates and presumed consequences that emerge from the data. Schwartz Model is used because it has a coherent and flexible structure with the measure instrument that has been evolved. Ten categories of Human Values and two dimensions are used to evaluate the Urban Environment. We will prove that the Human Value Conservation, through the dimensions: Conformity, Security and Tradition depends on the perceptions of the Urban Environment, specifically on the dimension Consumption/Esthetic \& Social Cohesion. We postulate tentatively that the Human Value Self-Enhancement, through the subdimensions Achievement and Power, it is a variable, which
\end{abstract}


in short and long time, impacts on the Perception of the Urban Environment, specifically on the Perception of the System of Generation and Distribution of Habitat Resource.

Keywords: Human values, Perception of the System of Generation and Distribution of Habitat Resource, Non-Lineal Partial Least Square Path Modeling, Overall satisfaction, Urban Environment, Job opportunities

\section{Introduction}

Human values are cultural and psychological mechanisms of accumulation of collective knowledge selected by the success in strengthening the reproduction of the group (Pinker, 2003), that are transformed in motivational goals that influence attitudes, behaviors and evaluations (Fischer \& Boer, 2016). Human values represent the responses that individuals and groups must give with three universal requirements:

1). The needs of people in their capacity as biological beings.

2). The coordination of social actions.

3). Survival and proper functioning of the groups (Schwartz, 2006).

These psychological mechanisms are the product of evolution and the interaction with the environment, where the values and preferences of the people arise (Kanazawa, 2009).

A gradual change in behavior allowed individuals to cope with different environmental conditions. Human values represent these psychological solutions that appealed humans, to face the challenges presented by the environment. Selective pressures imposed by the environment that promotes certain local characteristics are more adaptable than others (Newson et al., 2005). Systematically residents differ in both physiology and behavior, in fact, certain ecological characteristics exist that favor a strategy over another, and contribute differently to the structure and functioning of human psychology (O'Brien, 2012). Therefore, human values are motivational goals that influence attitudes, behavior and perceptions of the environment. There are personal, cultural variations, not in the structure of values but in the way that they interrelate, priorities, the intensity with which these values relate to the attitudes, behaviors or events of daily life and personal well-being (Fischer et al., 2016; Lindenberg, 1996).

\section{Background}

\subsection{Schwartz Human Values}

The analysis of value orientation of individuals from the conceptualizations of Schwartz $(1992,2001)$ that have empirical support for a classification of human values, verified in more than 60 countries will be taken, then extended to nineteen (Schwartz et al., 2012). In this article, we will work with the initial structure of ten values: Power, Achievement, Hedonism, Stimulation, Self-Determination, Universalism, Benevolence, Tradition, Conformity and Security, which are organized into four polarities of Self-promotion; Self-transcendence, Openness to change and Conservation. 
Theory expresses both motivations of opposite values together with values that are a continuum of related reasons. This results in a continuous circle structure. The nature of this continuum emphasizes the shared motivation types of values adjacent and nonadjacent that represent opposite types of values (Schwartz, 1992; 2001).

The value structure that is used at the individual level can be applied to cultures and societies. Social values are based on aggregated data at the individual level, and the same dimensions for individuals and societies are used. The structures at the individual level are replicated at the social level and the use of a single theoretical values organization allows a consistent and parsimonious study of cultural similarities and differences. (Inglehart et al., 2000; Wetzel, 2014; House et al., 2004; Fischer, 2010, 2012, 2013).

\subsection{Overall Satisfaction with the City}

The Overall satisfaction with the urban environment is described by four main factors: Urbanity and Diversity, Nature and Recreation, Job Opportunities and Cost-Efficiency. These four factors allow us to infer the sense of attachment to a place and the satisfaction of the citizens with their area of residence. They are relevant to the determination of possible sites that are pleasant (Zenker et al., 2014). They explain 50\% of the total variance of the satisfaction of citizens (Zenker et al., 2013; Nigro \& González Císaro, 2016; Zenker \& Gollan, 2010). In our case two constructs are used, based on three of the four factors: a) Perception of Generation and Distribution of Habitat Resources measured through the Job Opportunities and cost-efficiency, and b) Perception of Consumption / Esthetics \& Social Cohesion measured through Urbanity and Diversity. Perception of Generation and Distribution of Habitat Resources is based on the accumulation of Physical capital from strictly economic objectives (Kanazawa, 2009), measures the perception of the Habitat as a facilitator of accumulation of Physical Capital. Consumption / Esthetics \& Social Cohesion measure the perception of the Habitat as a facilitator of accumulation of Social Capital, the perception of the collective group ability to manage their social relationships, and tranquility for the development of everyday life with a variety of consumer goods and services. The Social Capital defines the resources generated from the relationships between individuals (Bourdieu et al., 1973, Bourdieu, 1984). Human beings are social only when and where they can reach reproductive success, but not otherwise. It is counted as capital only those relationships that directly or indirectly promote reproductive success of the individual (Kanazawa, 2010; Nigro \& González Císaro, 2016). This factor can include the concepts of Collective efficacy and / or Self-efficacy defined as the ability of the society to effectively achieve its objectives using these resources (Morenoff et al., 2001; Bandura, 1977). Regarding esthetics, there is evidence about the role of the architectural beauty of the urban environment in the accumulation of social capital (Dutton, 2003; Nigro \& González Císaro, 2016).

\section{The Research}

The employed methodology involves the construction of a causal theoretical model that follows a series of steps that connect the empirical context (data) with the same theoretical representation (model from reality). This model attempts to explain the relations between the 
latent variables included in the structural equation model from background knowledge inspired in the evolution of social sciences.

\subsection{Sample Description}

The research was developed on a general population with over 16 years of habitual residence in the places where was conducted the survey; the chosen cities were Tandil and Tres Arroyos at the Province of Buenos Aires, Argentina. A probabilistic sampling by cluster design, whose sampling error is $+/-4.7 \%$ with a significance level of $95 \%$, was employed; 438 cases were performed in a personal way. The sample can be considered fully representative of the population as the National census in Argentina in 2010. The survey was performed during December 2013 and January-February 2014. From 438 cases mentioned 50.1\% were women. The same number of surveys was taken in both cities, with an average age of 44.1 years (SD $=18.8$ ). Regarding the socioeconomic level, $7 \%$ of the sample is High, $47 \%$ and $46 \%$ are Medium Low. The educational level, $17 \%$ of the sample has completed tertiary or university education, 34\% has achieved an average educational level, i.e., they have at least completed high school and $48 \%$ have completed primary at the most.

The survey respondents were asked about the level of satisfaction that they have with the different dimensions of the city, based on the instruction: I want you to qualify from 1 to 10 the different characteristics of the city in terms of Very Unsatisfied, Unsatisfied, Neither satisfied nor unsatisfied, Satisfied, Very Satisfied. The items were measured with a Liker scale from 1 (Very Unsatisfied) to 10 (Very Satisfied).

As a method for the evaluation of the values, the survey respondents were exposed to a series of grouped stimuli in a set of stages, where imaginary subjects are protagonists, to which they have to indicate the level of adhesion

The measure version of the values that we used in this article is the PVQ of Schwartz (Shwartz et al., 2001), a PVQ adaptation of 40 items. The survey respondents answered to the instruction: "Next we will describe briefly some people. Please, read each description and think how much these persons resemble you or not. (1) He doesn't resemble me at all, (2-3) He doesn't resemble me (4-5) He resembles me very little (6-7) He resembles me a little (8-9) He rather resembles me (10) He resembles me a lot. At the end of the questionnaire we asked about sociodemographic attributes, Age, Educational Level and Incomes, and we recorded the Urbanization Level of the surveyed neighborhood.

\subsection{Descriptive Statistics}

Tables 1 to 3 show descriptive statistics for the sample. 
Table 1. Descriptive statistics of the dimensions that evaluate the area of residence. Urbanity and Diversity, Job Opportunities and Cost- Efficiency Relationship

\begin{tabular}{|c|c|c|}
\hline Items & Mean & $\begin{array}{l}\text { Standard } \\
\text { Deviation }\end{array}$ \\
\hline \multicolumn{3}{|c|}{$\begin{array}{l}\text { Urbanity and Diversity: metropolitan and urban characteristics of the place of residence. A city with a wide range of opportunities, cultural } \\
\text { events or availability of consumption and services. This factor describes a place, open and tolerant to diverse cultures and subcultures. }\end{array}$} \\
\hline Quantity and quality of cultural activities that take place in the city (theater, nightlife, etc.) & 6.9 & 2.0 \\
\hline Cultural diversity, variety of cultural events & 6.7 & 1.8 \\
\hline Openness and tolerance of the citizens & 5.8 & 1.9 \\
\hline Coexistence, environment and positive energy transmitted by the city & 7.0 & 1.7 \\
\hline Availability of different services & 7.3 & 1.9 \\
\hline Variety of shopping opportunities & 7.2 & 1.9 \\
\hline Degree of satisfaction with the urban visual image transmitted by the city & 7.7 & 1.7 \\
\hline \multicolumn{3}{|c|}{$\begin{array}{l}\text { Job Opportunities: It refers to all those factors related to the satisfaction with the Job Opportunities offered by the city, as well as the } \\
\text { general level of wages. }\end{array}$} \\
\hline General economic growth in the region. & 7.8 & 1.6 \\
\hline Existence and promotion of good jobs and job opportunities. & 6.3 & 2.0 \\
\hline The general level of wages. & 5.6 & 1.8 \\
\hline \multicolumn{3}{|l|}{ Cost / Efficiency ratio, profitability: Perception of the cost of living of the place. } \\
\hline Availability of apartments and houses. & 5.8 & 2.3 \\
\hline Housing market / Cost of hiring or renting. & 4.4 & 2.1 \\
\hline The general price level of the city / Cost of living. & 4.6 & 2.1 \\
\hline
\end{tabular}

The Dimension "Nature and Recreation" is not related to any Human Value, and therefore we did not decide to include it in the Model, as well as a second order construct that encompassed the initially latent variables of the first order Job Opportunities and Cost Efficiency Relationship, such as Perception of the Generation and Distribution of Habitat Resources (Nigro \& González Císaro, 2016) 
Table 2. Descriptive statistics, PVQ Schwartz (2001).

\begin{tabular}{|c|c|c|}
\hline & Mean & (SD) \\
\hline \multicolumn{3}{|l|}{ CONSERVATION-SECURITY } \\
\hline 5. Living in safe places. To avoid anything that could jeopardize your safety. & 7.88 & 2.29 \\
\hline $\begin{array}{l}\text { 14. It is very important for him / her that the Government guarantee him security against any threat. He } \\
\text { wants the state to be strong so that it can defend its citizens. }\end{array}$ & 8.53 & 1.82 \\
\hline 21. He cares about things that are in order and clean. He does not like things to be a mess. & 7.89 & 2.00 \\
\hline 31. He is very careful of not getting sick. For him / her it is very important to stay healthy. & 8.03 & 1.98 \\
\hline $\begin{array}{l}\text { 35. It is important for him / her that the government is stable. He is concerned about the maintenance of } \\
\text { the social order. }\end{array}$ & 8.58 & 1.49 \\
\hline \multicolumn{3}{|l|}{ CONSERVATION-CONFORMITY } \\
\hline $\begin{array}{l}\text { 7. Do you believe that people should do what they are told? Do you believe that people should follow } \\
\text { rules at all times, even when no one is watching? }\end{array}$ & 4.91 & 2.69 \\
\hline $\begin{array}{l}\text { 16. It is important for him / her to always behave correctly. He tries to avoid doing anything that others } \\
\text { think is wrong. }\end{array}$ & 7.15 & 2.46 \\
\hline $\begin{array}{l}\text { 28. He believes that he must always respect his parents and the elderly. It is important for him / her to } \\
\text { be obedient. }\end{array}$ & 8.31 & 1.70 \\
\hline 36. It is important to always be kind to everyone. He tries not to disturb or irritate others. & 7.93 & 1.97 \\
\hline \multicolumn{3}{|l|}{ CONSERVATION-TRADITION } \\
\hline $\begin{array}{l}\text { 9. He / she thinks it is important not to ask for more than he/she has. He believes that people should be } \\
\text { sa+tisfied with what they have. }\end{array}$ & 6.48 & 2.61 \\
\hline 20. Religious beliefs are important to him / her. He tries to do what his religion tells him to do. & 5.57 & 2.89 \\
\hline $\begin{array}{l}\text { 25. Believes that it is better to do things in the traditional way. It is important for him / her to keep the } \\
\text { customs he has learned. }\end{array}$ & 6.50 & 2.24 \\
\hline 38. It is important for him / her to be humble and modest. He tries not to attract attention. & 7.96 & 1.91 \\
\hline \multicolumn{3}{|l|}{ SELF-TRANSCENDENCE-BENEVOLENCE } \\
\hline $\begin{array}{l}\text { 12. It is very important for him / her to help the people around him / her. He cares about the welfare of } \\
\text { others. }\end{array}$ & 8.85 & 1.35 \\
\hline $\begin{array}{l}\text { 18. It is important for him / her to be loyal to their friends. He is totally given to people close to him / } \\
\text { her. }\end{array}$ & 8.62 & 1.57 \\
\hline 27. It is important for him / her to respond to the needs of others. He tries to support those he knows. & 8.63 & 1.26 \\
\hline $\begin{array}{l}\text { 33. For he / she it is important to forgive people who have hurt them. He tries to see the good in them } \\
\text { and do not resent them. }\end{array}$ & 7.06 & 2.27 \\
\hline SELF-TRANSCENDENCE-UNIVERSALISM & & \\
\hline
\end{tabular}




\begin{tabular}{|c|c|c|}
\hline $\begin{array}{l}\text { 3. He thinks it is important that all individuals in the world are treated equally. He believes that } \\
\text { everyone should have the same opportunities in life. }\end{array}$ & 8.50 & 1.86 \\
\hline $\begin{array}{l}\text { 8. It seems important to listen to people who are different from him / her. Even when he disagrees with } \\
\text { them, he still wants to understand them. }\end{array}$ & 7.87 & 1.88 \\
\hline $\begin{array}{l}\text { 19. He strongly believes that people should protect nature. It is important to take care of the } \\
\text { environment. }\end{array}$ & 8.65 & 1.55 \\
\hline $\begin{array}{l}\text { 23. He believes that all the inhabitants of the Earth should live in harmony. For him / her it is important } \\
\text { to promote peace among all groups in the world. }\end{array}$ & 8.62 & 1.46 \\
\hline $\begin{array}{l}\text { 29. He wants everyone to be treated fairly, including people he does not know. It is important to protect } \\
\text { the weakest. }\end{array}$ & 8.67 & 1.48 \\
\hline 40. It is important for him / her to adapt to Nature. He believes that people should not change Nature. & 7.98 & 1.80 \\
\hline \multicolumn{3}{|l|}{ OPENNESS TO CHANGE-SELF-DETERMINATION } \\
\hline 1. Having new ideas is important to him / her. He likes to do things in his own original way. & 7.34 & 2.05 \\
\hline $\begin{array}{l}\text { 11. It is important for him / her to make his /her own decisions about what he/she does. He likes to have } \\
\text { the freedom to plan and choose for himself / her activities, and not to depend on others. }\end{array}$ & 8.62 & 1.66 \\
\hline $\begin{array}{l}\text { 22. He believes that it is important to be interested in things. He likes to be curious and tries to } \\
\text { understand all sorts of things. }\end{array}$ & 7.56 & 1.88 \\
\hline 34. It is important for him / her to be independent. He likes to manage on his own. & 8.56 & 1.59 \\
\hline \multicolumn{3}{|l|}{ OPENNESS TO CHANGE- STIMULATION } \\
\hline $\begin{array}{l}6 . \mathrm{He} / \text { she thinks it is important to do many different things in life. He always seeks to experience new } \\
\text { things. }\end{array}$ & 7.30 & 2.23 \\
\hline 15. He likes to take risks. He is always looking for adventure. & 5.52 & 2.70 \\
\hline 30. He likes surprises. Having a life full of emotions is important to him / her & 7.44 & 1.97 \\
\hline \multicolumn{3}{|l|}{ OPENNESS TO CHANGE- HEDONISM } \\
\hline 10. He finds any opportunity to have fun. For him / her it is important to do things that please him / her. & 7.33 & 2.38 \\
\hline 26. Enjoying the pleasures of life is important to him / her. He likes to "indulge" himself. & 7.70 & 1.85 \\
\hline 37. He / she really wants to enjoy life. Having a good time is very important for him / her. & 8.39 & 1.59 \\
\hline \multicolumn{3}{|l|}{ SELF-GROWTH - POWER } \\
\hline 2. It is important for him / her to be rich. He wants to have lots of money and expensive things. & 3.07 & 2.33 \\
\hline 17. It is important for him / her to tell others what to do. He wants people to do what he tells them. & 3.93 & 2.46 \\
\hline 39. He / she always wants to be the one who makes the decisions. He likes to be a leader. & 5.85 & 2.41 \\
\hline \multicolumn{3}{|l|}{ SELF-GROWTH - ACHIEVEMENT } \\
\hline $\begin{array}{l}\text { 4. For him / her it is very important to show his/her skills. He wants people to admire him for what he } \\
\text { does. }\end{array}$ & 5.54 & 2.67 \\
\hline
\end{tabular}




\begin{tabular}{|l|l|l|}
\hline $\begin{array}{l}\text { 13. It is very important for him / her to be a successful person. He likes to impress people and that } \\
\text { people recognize his accomplishments. }\end{array}$ & 5.16 & 2.62 \\
\hline 24. He thinks that is important to be ambitious. He wants to show how capable he is. & 4.53 & 2.40 \\
\hline 32. Progressing in life is important to him / her. He strives to be better than others. & 6.82 & 2.31 \\
\hline
\end{tabular}

Table 3. Pearson correlations of the ten values with Age, Gender, Education and Socioeconomic Level

\begin{tabular}{|l|l|l|l|l|}
\hline & Age & Gender (Female) & Education & Socioeconomic- Level \\
\hline Security & $.284^{* *}$ & $.112^{*}$ & -.057 & -.032 \\
\hline Conformity & $.218^{* *}$ & .009 & -.075 & -.023 \\
\hline Tradition & $.292^{* *}$ & $.111^{*}$ & $-.250^{* *}$ & $-.189^{* *}$ \\
\hline Benevolence & $.115^{*}$ & .077 & .076 & -.027 \\
\hline Universalism & $.148^{* *}$ & $.098^{*}$ & $.174^{* *}$ & .037 \\
\hline Self-Direction & .055 & .011 & $.237^{* *}$ & $.095^{*}$ \\
\hline Stimulation & $-.209^{* *}$ & -.022 & $.138^{* *}$ & .068 \\
\hline Hedonism & $-.105^{*}$ & .013 & .072 & .085 \\
\hline Achievement & -.061 & -.063 & .032 & .093 \\
\hline Power & .012 & $-.142^{* *}$ & .010 & $.107^{*}$ \\
\hline
\end{tabular}

**. correlation is significant at label 0.01 (bilateral). *. correlation is significant at 0.05 (bilateral).

\section{Model and Main Results}

The objective sought by the PLS (Partial Least Square) modeling is to predict (both latent and manifest) dependent variables. This goal is translated to maximize the explained variance $\left(\mathrm{R}^{2}\right)$ of the dependent variables, which leads us to deduce that the estimates of the parameters are based on the ability to minimize the residual variances of endogenous variables. This type of model is more suitable for applications prediction (Anderson \& Gerbing, 1988; Chin et al., 2003; Barclay et al., 1995) that require a certain exploratory theoretical development (Wold, 1979). They can also be used for theoretical confirmation through confirmatory analysis.

The SEM algorithm of Warp3 PLS regression is used for analysis selecting a Bootstrapping as sampling method. The Warp3 PLS algorithm tries to identify a relationship defined by a function whose first derivative is a curve U. This relationship follows a pattern that resembles more closely a curve that approaches an $\mathrm{S}$, and it can be a combination of a $\mathrm{U}$ linked to two curves, one of which is inverted (Kock, 2013). 


\subsection{First-order Latent Variables}

The first-order latent variables corresponding to each human value are calculated, a total of ten, and the loads of the manifest variables corresponding to each item are verified so they result greater than 0.5 .

Therefore, the items 7 and 33 are removed. Item 7, "Do you believe that people should do what they are told? Do you believe that people should follow rules at all times, even when no one is watching?", corresponding to Human Value Compliance. Item 33 "For he / she is important to forgive people who have hurt you. Try to see the good in them and do not resent them." corresponding to Human Value Benevolence. 
Table 4. Combined and transverse loadings. Loadings are without rotating. The transverse loadings have oblique rotation

\begin{tabular}{|c|c|c|c|c|c|c|c|c|c|c|c|c|c|}
\hline & SelfDir & Estimul & Hedonis & Power & Achivie & Securit & Conform & Traditi & Benevol & Univers & Type (a & SE & P value \\
\hline Ítem 1 & 0.702 & 0.040 & -0.170 & -0.074 & 0.043 & -0.086 & -0.033 & 0.025 & 0.019 & 0.126 & Reflect & 0.044 & $<0.001$ \\
\hline Ítem 11 & 0.665 & -0.051 & 0.066 & 0.129 & -0.086 & 0.008 & -0.045 & 0.008 & 0.027 & -0.081 & Reflect & 0.044 & $<0.001$ \\
\hline Ítem 22 & 0.594 & 0.100 & 0.040 & -0.134 & 0.098 & 0.157 & 0.036 & -0.131 & -0.028 & 0.127 & Reflect & 0.044 & $<0.001$ \\
\hline Ítem 34 & 0.689 & -0.077 & 0.076 & 0.066 & -0.045 & -0.055 & 0.046 & 0.079 & -0.021 & -0.160 & Reflect & 0.044 & $<0.001$ \\
\hline Ítem 6 & 0.181 & 0.766 & -0.218 & -0.098 & -0.018 & -0.127 & 0.193 & -0.030 & 0.059 & 0.001 & Reflect & 0.043 & $<0.001$ \\
\hline Ítem 15 & $5-0.052$ & 0.748 & 0.053 & 0.197 & -0.045 & -0.105 & -0.049 & -0.025 & -0.177 & 0.137 & Reflect & 0.043 & $<0.001$ \\
\hline Ítem 30 & -0.140 & 0.710 & 0.180 & -0.102 & 0.067 & 0.248 & -0.157 & 0.059 & 0.123 & -0.145 & Reflect & 0.044 & $<0.001$ \\
\hline Ítem 10 & 0.017 & 0.133 & 0.729 & -0.036 & -0.057 & -0.065 & -0.053 & 0.027 & -0.079 & -0.031 & Reflect & 0.043 & $<0.001$ \\
\hline Ítem 26 & 60.011 & -0.054 & 0.758 & 0.013 & 0.057 & 0.105 & -0.158 & 0.032 & 0.031 & -0.086 & Reflect & 0.043 & $<0.001$ \\
\hline Ítem 37 & 7-0.025 & -0.068 & 0.833 & 0.019 & -0.001 & -0.039 & 0.191 & -0.053 & 0.041 & 0.106 & Reflect & 0.043 & $<0.001$ \\
\hline Ítem 2 & -0.036 & 0.122 & -0.026 & 0.545 & 0.259 & 0.124 & 0.028 & -0.309 & -0.061 & -0.139 & Reflect & 0.044 & $<0.001$ \\
\hline Ítem 17 & 7-0.039 & -0.158 & 0.088 & 0.776 & -0.034 & -0.056 & 0.081 & 0.180 & -0.158 & 0.140 & Reflect & 0.043 & $<0.001$ \\
\hline Ítem 39 & 0.070 & 0.078 & -0.076 & 0.714 & -0.161 & -0.034 & -0.110 & 0.041 & 0.219 & -0.046 & Reflect & 0.044 & $<0.001$ \\
\hline Ítem 4 & 0.021 & -0.035 & -0.144 & -0.063 & 0.733 & -0.113 & 0.050 & 0.041 & 0.086 & 0.094 & Reflect & 0.043 & $<0.001$ \\
\hline Ítem 13 & 0.037 & -0.002 & -0.033 & -0.046 & 0.812 & 0.013 & -0.027 & 0.081 & -0.019 & -0.047 & Reflect & 0.043 & $<0.001$ \\
\hline Ítem 24 & 4-0.009 & -0.001 & 0.025 & 0.155 & 0.690 & 0.028 & -0.204 & -0.128 & -0.040 & 0.054 & Reflect & 0.044 & $<0.001$ \\
\hline Ítem 32 & $2-0.069$ & 0.050 & 0.207 & -0.041 & 0.559 & 0.095 & 0.225 & -0.013 & -0.036 & -0.123 & Reflect & 0.044 & $<0.001$ \\
\hline Ítem 5 & -0.042 & 0.209 & -0.318 & -0.016 & 0.175 & 0.665 & 0.024 & 0.025 & 0.115 & -0.304 & Reflect & 0.044 & $<0.001$ \\
\hline Ítem 14 & 4-0.146 & -0.072 & 0.130 & -0.008 & -0.051 & 0.745 & -0.097 & -0.196 & 0.103 & 0.044 & Reflect & 0.043 & $<0.001$ \\
\hline Ítem 21 & 0.182 & 0.088 & -0.100 & 0.018 & -0.093 & 0.575 & 0.223 & 0.251 & -0.172 & 0.056 & Reflect & 0.044 & $<0.001$ \\
\hline Ítem 31 & 0.046 & -0.076 & 0.050 & -0.030 & 0.141 & 0.595 & -0.061 & 0.203 & -0.029 & 0.024 & Reflect & 0.044 & $<0.001$ \\
\hline Ítem 35 & 50.006 & -0.125 & 0.197 & 0.034 & -0.151 & 0.724 & -0.049 & -0.188 & -0.051 & 0.169 & Reflect & 0.043 & $<0.001$ \\
\hline Ítem 7 & -0.220 & 0.236 & -0.330 & 0.341 & 0.023 & 0.064 & 0.213 & 0.191 & 0.028 & -0.032 & Reflect & 0.046 & $<0.001$ \\
\hline Ítem 16 & 60.059 & 0.040 & -0.132 & -0.038 & 0.035 & -0.074 & 0.775 & -0.007 & 0.030 & -0.266 & Reflect & 0.043 & $<0.001$ \\
\hline Ítem 28 & 0.045 & 0.024 & 0.030 & 0.046 & -0.094 & 0.032 & 0.772 & 0.062 & 0.061 & -0.045 & Reflect & 0.043 & $<0.001$ \\
\hline Ítem 36 . & 6-0.044 & -0.128 & 0.193 & -0.101 & 0.052 & 0.024 & 0.779 & -0.106 & -0.098 & 0.318 & Reflect & 0.043 & $<0.001$ \\
\hline Ítem 9 & 0.093 & 0.113 & -0.007 & -0.033 & -0.107 & -0.064 & -0.044 & 0.724 & -0.119 & -0.004 & Reflect & 0.043 & $<0.001$ \\
\hline Ítem 20 & -0.144 & 0.135 & -0.296 & 0.071 & 0.147 & 0.149 & -0.230 & 0.541 & 0.144 & -0.045 & Reflect & 0.044 & $<0.001$ \\
\hline Ítem 25 & $5-0.074$ & -0.071 & 0.112 & 0.075 & -0.017 & 0.153 & -0.122 & 0.718 & -0.006 & -0.122 & Reflect & 0.043 & $<0.001$ \\
\hline
\end{tabular}


ISSN 2329-9150

\begin{tabular}{|c|c|c|c|c|c|c|c|c|c|c|c|c|c|}
\hline Ítem 38 & 0.104 & -0.171 & 0.140 & -0.112 & 0.017 & -0.237 & 0.400 & 0.608 & 0.021 & 0.189 & Reflect & 0.044 & $<0.001$ \\
\hline Ítem 12 & 0.084 & -0.021 & -0.063 & -0.006 & 0.013 & -0.014 & 0.089 & -0.069 & 0.751 & 0.153 & Reflect & 0.043 & $<0.001$ \\
\hline Ítem 18 & -0.097 & 0.096 & 0.031 & -0.021 & 0.071 & -0.028 & -0.013 & -0.166 & 0.707 & -0.113 & Reflect & 0.044 & $<0.001$ \\
\hline Ítem 27 & $7-0.016$ & -0.043 & 0.069 & 0.072 & -0.116 & 0.145 & -0.061 & 0.016 & 0.810 & -0.110 & Reflect & 0.043 & $<0.001$ \\
\hline Ítem 33 & 0.041 & -0.039 & -0.067 & -0.089 & 0.077 & -0.198 & -0.017 & 0.355 & 0.442 & 0.121 & Reflect & 0.045 & $<0.001$ \\
\hline Ítem 3 & 0.063 & -0.071 & -0.008 & -0.100 & -0.052 & -0.045 & -0.046 & -0.098 & -0.178 & 0.545 & Reflect & 0.044 & $<0.001$ \\
\hline Ítem 8 & -0.080 & 0.347 & -0.102 & -0.036 & -0.014 & -0.164 & 0.154 & -0.173 & 0.220 & 0.554 & Reflect & 0.044 & $<0.001$ \\
\hline Ítem 19 & 0.008 & -0.060 & -0.060 & 0.055 & 0.044 & -0.007 & -0.129 & 0.062 & 0.003 & 0.757 & Reflect & 0.043 & $<0.001$ \\
\hline Ítem 23 & 0.116 & -0.178 & 0.080 & -0.147 & 0.058 & 0.055 & -0.083 & 0.059 & -0.068 & 0.771 & Reflect & 0.043 & $<0.001$ \\
\hline Ítem 29 & -0.046 & 0.047 & 0.029 & -0.005 & -0.011 & -0.039 & 0.291 & -0.162 & 0.116 & 0.782 & Reflect & 0.043 & $<0.001$ \\
\hline Ítem 40 & -0.068 & -0.011 & 0.031 & 0.207 & -0.045 & 0.150 & -0.173 & 0.252 & -0.091 & 0.725 & Reflect & 0.043 & $<0.001$ \\
\hline
\end{tabular}




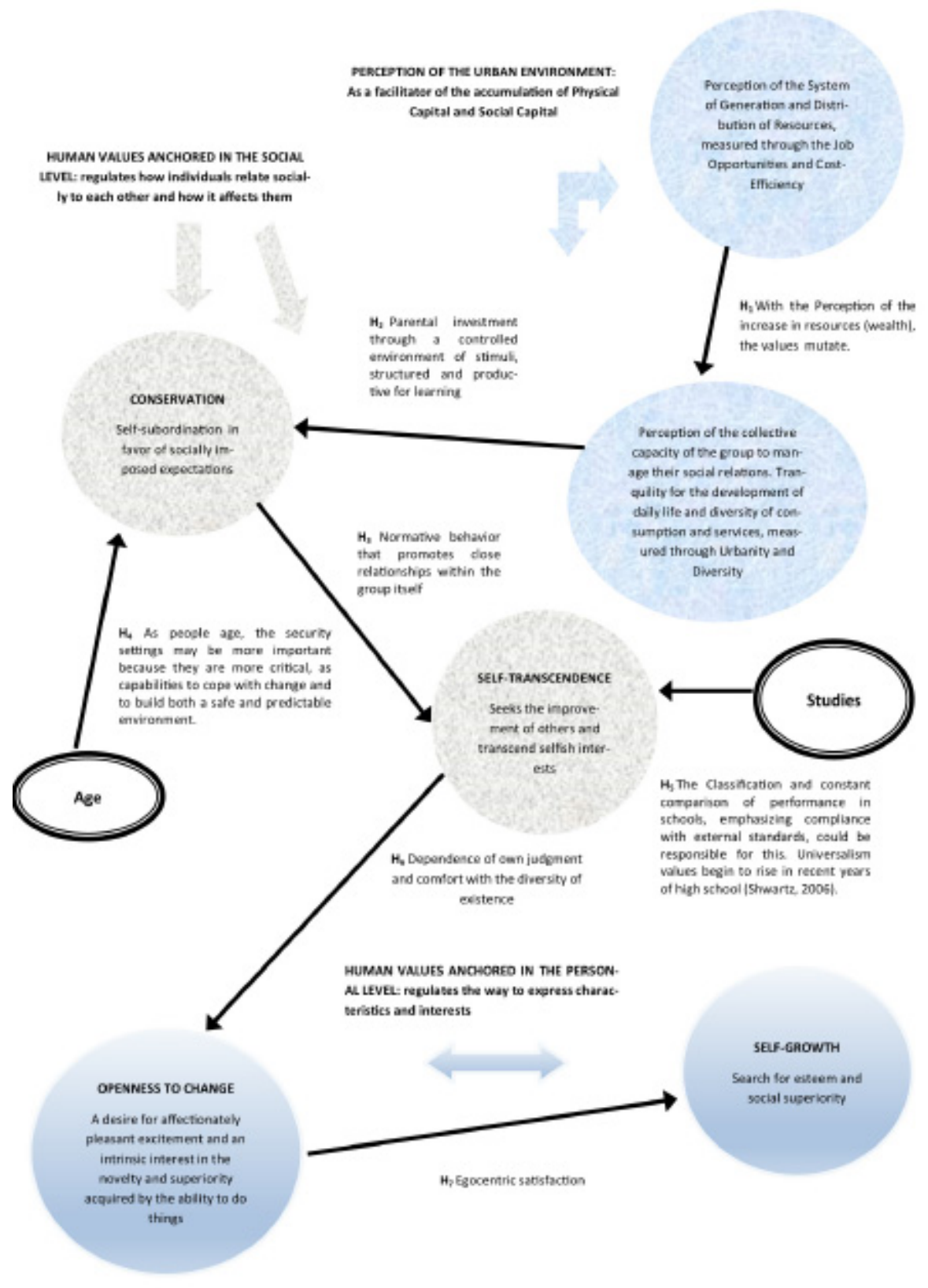

Figure 1. Proposed Inner Model

The Human Value Hedonism shares elements of openness to change and self-enhancement. In our case, we prefer to include it in openness to change. (Schwartz, 2012)

Then, convergent validity is verified for associated dimensions to urban evaluation, and first-order variables: job opportunities, Cost-efficiency relationship, Esthetics and diversity of consumer goods and services and social cohesion. Figure 1 exhibits the proposed model.

Table 5. Combined and transverse loadings for the latent variables that measure the two dimensions of satisfaction with the city in which the respondent resides 


\begin{tabular}{|c|c|c|c|c|c|c|c|}
\hline & $\begin{array}{l}\text { Job } \\
\text { opportunities }\end{array}$ & $\begin{array}{l}\text { Cost-efficiency } \\
\text { relationship }\end{array}$ & $\begin{array}{l}\text { Esthetics and } \\
\text { diversity of } \\
\text { consumer goods } \\
\text { and services }\end{array}$ & $\begin{array}{l}\text { Social } \\
\text { cohesion }\end{array}$ & Type (a) & SE & $P$ value \\
\hline $\begin{array}{l}\text { General economic growth } \\
\text { in the region. }\end{array}$ & 0.739 & -0.069 & 0.219 & -0.019 & Reflect & 0.043 & $<0.001$ \\
\hline $\begin{array}{l}\text { Existence of good jobs and } \\
\text { promotion of employment } \\
\text { opportunities }\end{array}$ & 0.839 & -0.060 & -0.069 & 0.072 & Reflect & 0.043 & $<0.001$ \\
\hline The general level of wages & 0.752 & 0.135 & -0.138 & -0.061 & Reflect & 0.043 & $<0.001$ \\
\hline $\begin{array}{l}\text { The general level of prices } \\
\text { in the city / cost of living. }\end{array}$ & 0.350 & 0.734 & -0.006 & -0.094 & Reflect & 0.043 & $<0.001$ \\
\hline $\begin{array}{l}\text { Availability of apartments } \\
\& \text { houses. }\end{array}$ & -0.125 & 0.795 & 0.078 & 0.049 & Reflect & 0.043 & $<0.001$ \\
\hline $\begin{array}{l}\text { Housing market / Cost of } \\
\text { hiring rental or purchase. }\end{array}$ & -0.185 & 0.853 & -0.068 & 0.035 & Reflect & 0.043 & $<0.001$ \\
\hline $\begin{array}{l}\text { Availability of different } \\
\text { services. }\end{array}$ & -0.065 & -0.087 & 0.822 & 0.118 & Reflect & 0.043 & $<0.001$ \\
\hline $\begin{array}{l}\text { Variety of shopping } \\
\text { opportunities. }\end{array}$ & 0.010 & 0.108 & 0.717 & -0.186 & Reflect & 0.043 & $<0.001$ \\
\hline $\begin{array}{l}\text { Are you satisfied with } \\
\text { urban visual image that } \\
\text { conveys the city? }\end{array}$ & 0.061 & -0.008 & 0.756 & 0.048 & Reflect & 0.043 & $<0.001$ \\
\hline $\begin{array}{l}\text { Quantity and quality of } \\
\text { cultural activities } \\
\text { developed in the city } \\
\text { (theater, nightlife, etc.) }\end{array}$ & 0.040 & -0.160 & 0.079 & 0.825 & Reflect & 0.043 & $<0.001$ \\
\hline $\begin{array}{l}\text { Cultural diversity, } \\
\text { different cultures and } \\
\text { subcultures. }\end{array}$ & 0.036 & -0.148 & 0.092 & 0.806 & Reflect & 0.043 & $<0.001$ \\
\hline $\begin{array}{l}\text { Openness and tolerance of } \\
\text { citizens. }\end{array}$ & -0.061 & 0.254 & -0.169 & 0.628 & Reflect & 0.044 & $<0.001$ \\
\hline $\begin{array}{l}\text { Cohabitation, environment } \\
\text { and positive energy that } \\
\text { transmits the city. }\end{array}$ & -0.033 & 0.126 & -0.046 & 0.724 & Reflect & 0.043 & $<0.001$ \\
\hline
\end{tabular}

Loadings are without rotating. The transverse loadings have oblique rotation. For reflective indicators are expected values of $\mathrm{p}<0.05$ 


\section{Macrothink $\underline{\text { Mnstitute }}{ }^{\mathrm{m}}$}

Table 4 and 5 describe the convergent validity of the measuring instrument. A measuring instrument has a good convergent validity if the manifest variables (or other measures) associated with each latent variable are understood by respondents in the same manner as they were meant by the designers of the manifest variables. The values SP and P are only for loadings. They have expected values of $p<0.05$ for reflective indicators and loadings equal to or greater than 0.5 (Hair et al., 2009), the indicators for which these criteria are not met can be removed.

\section{General Model Result}

After adjusting the items that do not meet the criteria of convergent validity, the model with second-order latent variables is calculated. Table 6 shows overall results.

Table 6. Model fit and quality indexes

\begin{tabular}{l} 
Average path coefficient $(\mathrm{APC})=0.404, \mathrm{P}<0.001$ \\
Average R-squared (ARS) $=0.261, \mathrm{P}<0.001$ \\
Average adjusted R-squared (AARS) $=0.259, \mathrm{P}<0.001$ \\
Average block VIF (AVIF) $=1.032$, acceptable if $<=5$, ideally $<=3.3$ \\
Average full collinearity VIF (AFVIF) $=1.534$, acceptable if $<=5$, ideally $<=3.3$ \\
\hline Tenenhaus GoF (GoF) $=0.457$, small $>=0.1$, medium $>=0.25$, large $>=0.36$ \\
\hline Sympson's paradox ratio $(\mathrm{SPR})=1.000$, acceptable if $>=0.7$, ideally $=1$ \\
\hline R-squared contribution ratio $(\mathrm{RSCR})=1.000$, acceptable if $>=0.9$, ideally $=1$ \\
\hline Statistical suppression ratio $(\mathrm{SSR})=1.000$, acceptable if $>=0.7$ \\
\hline Nonlinear bivariate causality direction ratio $(\mathrm{NLBCDR})=1.000$, acceptable if $>=0.7$ \\
\hline
\end{tabular}

The relationship between loadings and second-order latent variables are shown in Tables 7 to 10.

Table 7. Normalized combined and Cross-Loadings.

\begin{tabular}{|l|l|l|l|l|l|l|l|l|}
\hline & Self_tras & Ope_change & Recurse & Conserv & Age & Education & Self-Enhancement & Urb\&Div \\
\hline Benevolence & $\mathbf{0 . 7 6 7}$ & 0.025 & 0.022 & -0.167 & -0.038 & -0.126 & 0.026 & 0.005 \\
\hline
\end{tabular}




\begin{tabular}{|l|l|l|l|l|l|l|l|l|}
\hline Universalism & $\mathbf{0 . 7 3 9}$ & -0.033 & -0.028 & 0.219 & 0.049 & 0.166 & -0.035 & -0.007 \\
\hline Self-Transcendence & 0.295 & $\mathbf{0 . 7 6 7}$ & -0.043 & -0.337 & 0.31 & 0.153 & 0.026 & 0.052 \\
\hline Stimulation & -0.089 & $\mathbf{0 . 8 2 2}$ & 0.02 & -0.051 & -0.139 & -0.086 & 0.029 & -0.01 \\
\hline Hedonism & -0.186 & $\mathbf{0 . 7 5 2}$ & 0.02 & 0.38 & -0.144 & -0.052 & -0.057 & -0.039 \\
\hline Job Opportunities & -0.161 & 0.104 & $\mathbf{0 . 8 4 5}$ & 0.115 & 0.007 & 0.166 & -0.063 & 0.165 \\
\hline Cost-efficiency & 0.137 & -0.089 & $\mathbf{0 . 9 0 8}$ & -0.099 & -0.006 & -0.142 & 0.054 & -0.141 \\
\hline relationship & -0.062 & -0.076 & 0.067 & $\mathbf{0 . 7 6 2}$ & -0.049 & -0.161 & 0.004 & 0.012 \\
\hline Tradition & -0.028 & -0.047 & 0.004 & $\mathbf{0 . 7 6 6}$ & -0.065 & 0.076 & 0.004 & -0.013 \\
\hline Conformity & 0.119 & 0.163 & -0.091 & $\mathbf{0 . 7 1 4}$ & 0.153 & 0.102 & -0.01 & 0.002 \\
\hline Security & 0.000 & 0.000 & 0.000 & 0.000 & $\mathbf{1 . 0 0 0}$ & 0.000 & 0.000 & 0.000 \\
\hline Age & 0.000 & 0.000 & 0.000 & 0.000 & 0.000 & $\mathbf{1 . 0 0 0}$ & 0.000 & 0.000 \\
\hline Education & 0.070 & -0.107 & -0.032 & -0.104 & 0.086 & 0.004 & $\mathbf{0 . 9 3 6}$ & 0.020 \\
\hline Power & -0.080 & 0.121 & 0.036 & 0.118 & -0.098 & -0.004 & $\mathbf{0 . 8 7 1}$ & -0.023 \\
\hline Achievement & 0.114 & -0.053 & -0.086 & -0.083 & 0.005 & -0.048 & 0.126 & -0.132 \\
\hline Social Cohesion & -0.120 & 0.056 & 0.090 & 0.087 & -0.006 & 0.051 & $\mathbf{0 . 8 1 7}$ \\
\hline Consume\& Esthetic & & & & & 0.820 \\
\hline
\end{tabular}

Table 8. Latent variable coefficients

\begin{tabular}{|l|l|l|l|l|l|l|l|}
\hline & $\begin{array}{l}\text { R-squared } \\
\text { coefficients }\end{array}$ & $\begin{array}{l}\text { Adjusted } \\
\text { R-squared } \\
\text { coefficients }\end{array}$ & $\begin{array}{l}\text { Composite } \\
\text { reliability } \\
\text { coefficients }\end{array}$ & $\begin{array}{l}\text { Cronbach's } \\
\text { alpha } \\
\text { coefficients }\end{array}$ & $\begin{array}{l}\text { Average } \\
\text { variances } \\
\text { extracted }\end{array}$ & $\begin{array}{l}\text { Full } \\
\text { collinearity } \\
\text { VIFs }\end{array}$ & $\begin{array}{l}\text { Q-squared } \\
\text { coefficients }\end{array}$ \\
\hline Conservation & 0.216 & 0.213 & 0.882 & 0.799 & 0.713 & 1.952 & 0.218 \\
\hline Self-Transcendence & 0.462 & 0.459 & 0.886 & 0.742 & 0.795 & 2.219 & 0.460 \\
\hline Openness to Change & 0.291 & 0.289 & 0.851 & 0.738 & 0.657 & 1.738 & 0.291 \\
\hline Self-Enhancement & 0.121 & 0.119 & 0.852 & 0.653 & 0.742 & 1.227 & 0.122 \\
\hline Job Opportunities & & & 0.839 & 0.616 & 0.723 & 1.303 & 1.440 \\
\hline Urbanity\&Diversity & 0.217 & 0.215 & 0.875 & 0.714 & 0.777 & 0.219 \\
\hline Age & & & 1.000 & 1.000 & 1.000 & 1.223 & 1.172 \\
\hline Education & & & 1.000 & 1.000 & 1.000 & \\
\hline
\end{tabular}

The relaxed version is that only one of the two coefficients (Composite Reliability and Cronbach's alpha coefficients) must be equal to or greater than 0.7 . This usually applies to the composite reliability coefficients, which is usually the greater of the two (Fornell \& Larcker, 1981). 
Table 9. Correlations among l.vs. with sq. rts. of AVEs

\begin{tabular}{|l|l|l|l|l|l|l|l|l|}
\hline & Conserv & Self-trans & Ope-change & Self-Growing & Job_opp & Urb\&Div & Age & Education \\
\hline Conservation & $(0.845)$ & 0.613 & 0.335 & 0.149 & 0.157 & 0.346 & 0.291 & -0.152 \\
\hline Self-Transcendence & 0.613 & $(0.892)$ & 0.537 & 0.061 & 0.020 & 0.235 & 0.140 & 0.118 \\
\hline Openness to Change & 0.335 & 0.537 & $(0.810)$ & 0.347 & 0.090 & 0.156 & -0.108 & 0.178 \\
\hline Self-Enhancement & 0.149 & 0.061 & 0.347 & $(0.862)$ & 0.190 & 0.180 & -0.021 & 0.022 \\
\hline Job Opportunities & 0.157 & 0.020 & 0.090 & 0.190 & $(0.850)$ & 0.452 & 0.052 & -0.081 \\
\hline Urbanity\&Diversity & 0.346 & 0.235 & 0.156 & 0.180 & 0.452 & $(0.882)$ & 0.211 & -0.057 \\
\hline Age & 0.291 & 0.140 & -0.108 & -0.021 & 0.052 & 0.211 & $(1.000)$ & -0.250 \\
\hline Education & -0.152 & 0.118 & 0.178 & 0.022 & -0.081 & -0.057 & -0.250 & $(1.000)$ \\
\hline
\end{tabular}

Square roots of average variances extracted (AVEs) shown on diagonal. The square root of the AVE should be greater than any of the correlations that include the latent variable (Fornell \& Larcker, 1981).

Table 10. Path coefficients and $\mathrm{P}$ values

\begin{tabular}{|c|c|c|c|c|c|c|c|c|}
\hline & Self-Transcendence & $\begin{array}{l}\text { Openness } \\
\text { to Change }\end{array}$ & $\begin{array}{l}\text { Job } \\
\text { Opportunities }\end{array}$ & Conservation & Age & Education & $\begin{array}{l}\text { Self-Enhanc } \\
\text { ement }\end{array}$ & $\begin{array}{l}\text { Urbanity } \\
\text { \&Diversity }\end{array}$ \\
\hline Self-Transcendence & & & & $\begin{array}{l}0.651 \\
<0.001\end{array}$ & & $\begin{array}{l}0.246 \\
<0.001\end{array}$ & & \\
\hline Openness to Change & $\begin{array}{l}0.539 \\
<0.001\end{array}$ & & & & & & & \\
\hline Job Opportunities & & & & & & & & \\
\hline Conservation & & & & & $\begin{array}{l}0.20 \\
<0.001\end{array}$ & & & $\begin{array}{l}0.371 \\
<0.001\end{array}$ \\
\hline Age & & & & & & & & \\
\hline Education & & & & & & & & \\
\hline Self-Enhancement & & $\begin{array}{l}0.347 \\
<0.001\end{array}$ & & & & & & \\
\hline Urbanity\&Diversity & & & $\begin{array}{l}0.465 \\
<0.001\end{array}$ & & & & & \\
\hline
\end{tabular}

\subsection{Proved Hypotheses and Theoretical Interpretation}


$H_{l}$. When the Habitat Perception as a
facilitator of Physical Capital
accumulation improves, it improves the
Perception of the same as a facilitator of accumulation of the Social Capital, measured mainly through the Consumption capacity of the area of residence.

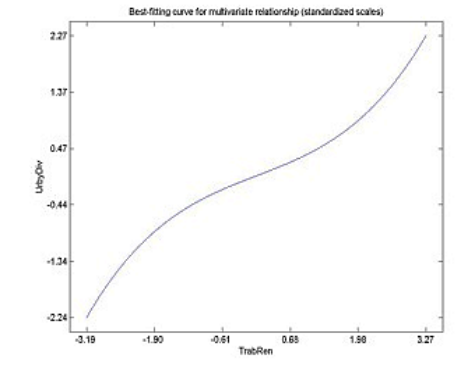

$\mathrm{H}_{2}$. When the perception of the results of the socialization of the group to which the individuals belong is very low or very high, the human values linked to Conservation become much stronger.

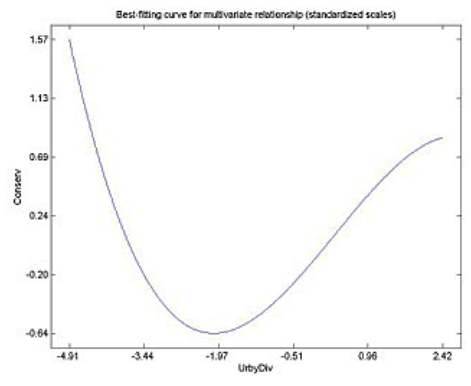

$H_{3 .}$ At an older age, adherence to human value preservation increases.
People consume primarily by their status cravings, to establish social relationships and thereby improve their social capital (Heffetz \& Frank, 2008). The success of the cities depends more and more on their role as centers of consumption (Glaeser, et al., 2000, 2006).

In individual terms, the parents make an investment in time and energy to provide an environment in which they have control over the different stimuli that receive their children, providing them structured and productive means for learning. Maternal care is one of the foundations of later altruistic behavior (Burkart et al., 2009; Churchland, 2011).

A senior age is the correlation with the human value Conservation, either by physical aging or the stage of life they are in, for example, parenting, widowhood, etc. (see Table 3). Strength, energy, cognitive speed, memory and acuteness of the senses diminish with age. Although the onset and the rate of descent vary greatly, rarely the decline is reversed. (Schwartz, 2001). 


\section{Macrothink}

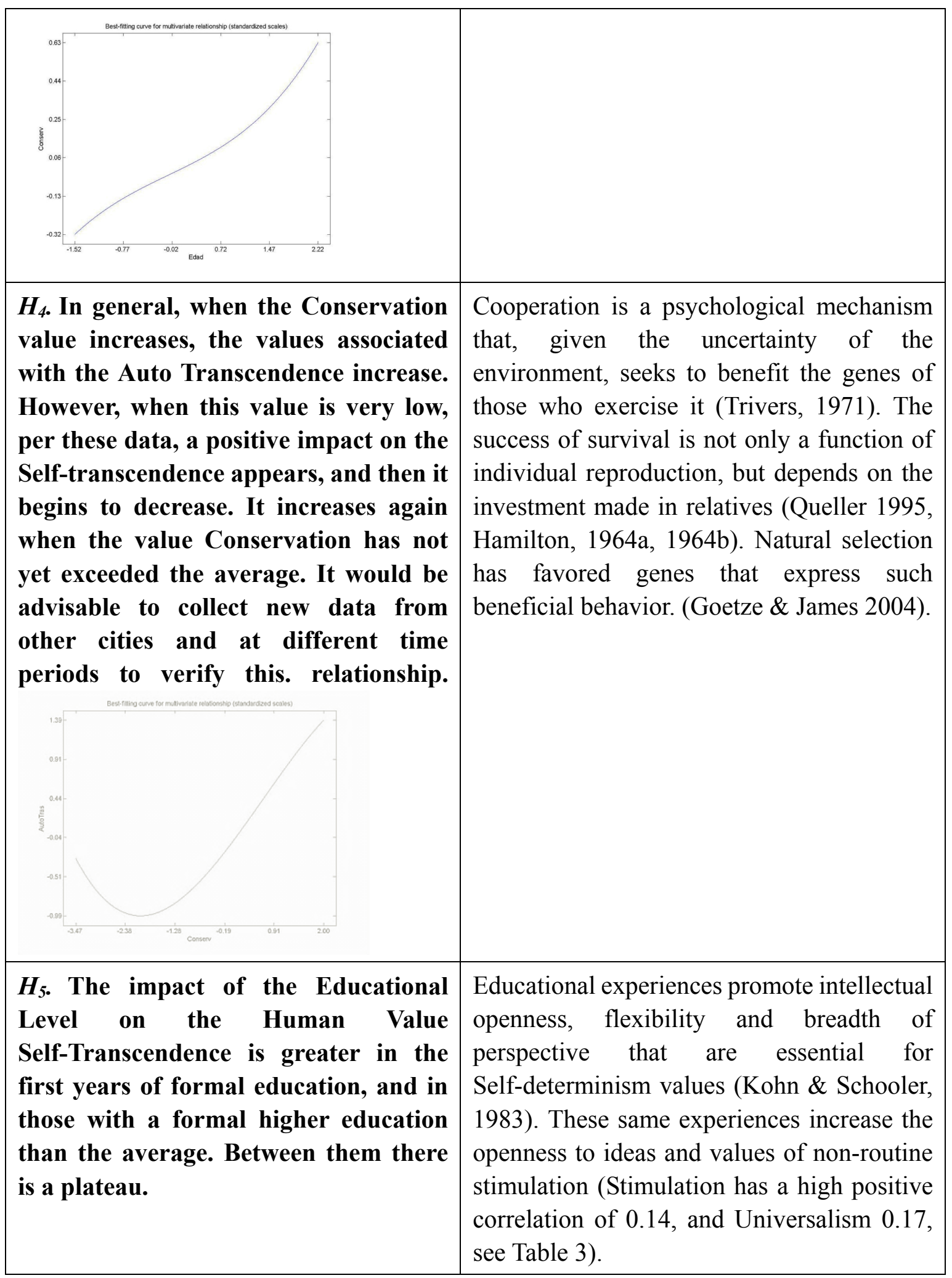




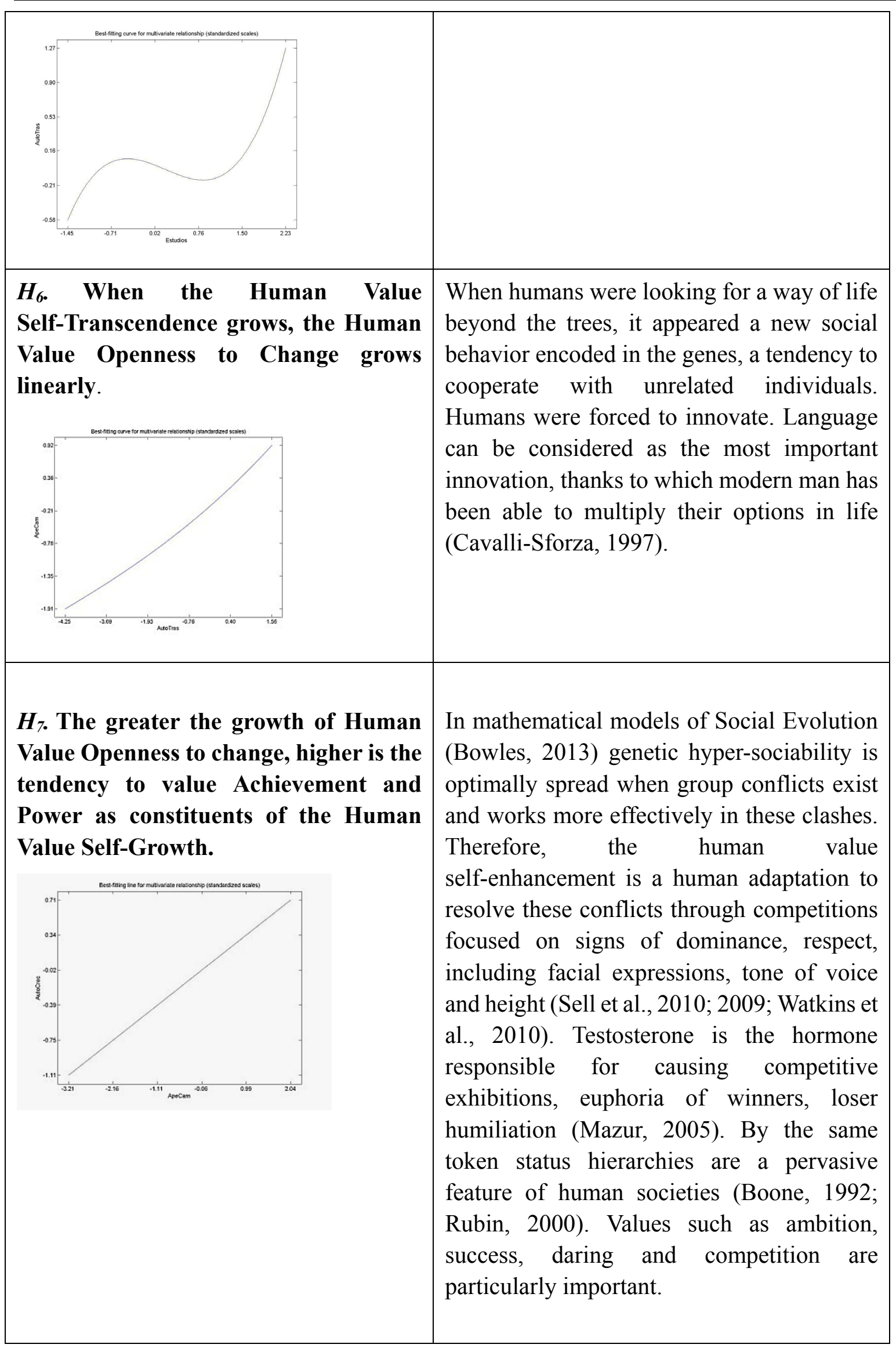




\subsection{Segmentation PLS-PM with Pathmox Algorithm}

We use the socio-demographic variables, gender, age, studies, income, and urbanization level of the zone, as segmentation variables of a structural equations model, through Pathmox algorithm. The Pathmox algorithm is based on a segmentation strategy like a decision tree, specifically designed when you have previous information in the form of external variables (socio-demographic variables). The inner models are compared by an extension that tests the equality of two regression models; and the external ones are compared using the Ryan-Joiner correlation test (Sánchez \& Aluja, 2006).

The variables urbanization level of the zone of residence and age have been shown to be the significant segmentation variables through the results obtained by the algorithm Pathmox (see Figure 2).

The algorithm has segmented the population into four nodes. Each segment can be interpreted as a cognitive niche (Curry, 2016). For example, Node 5 represents about 84 individuals aged thirty years or older, who live in areas of good urbanization level. The indicators of the segmentation are shown in Tables 11 and 12.

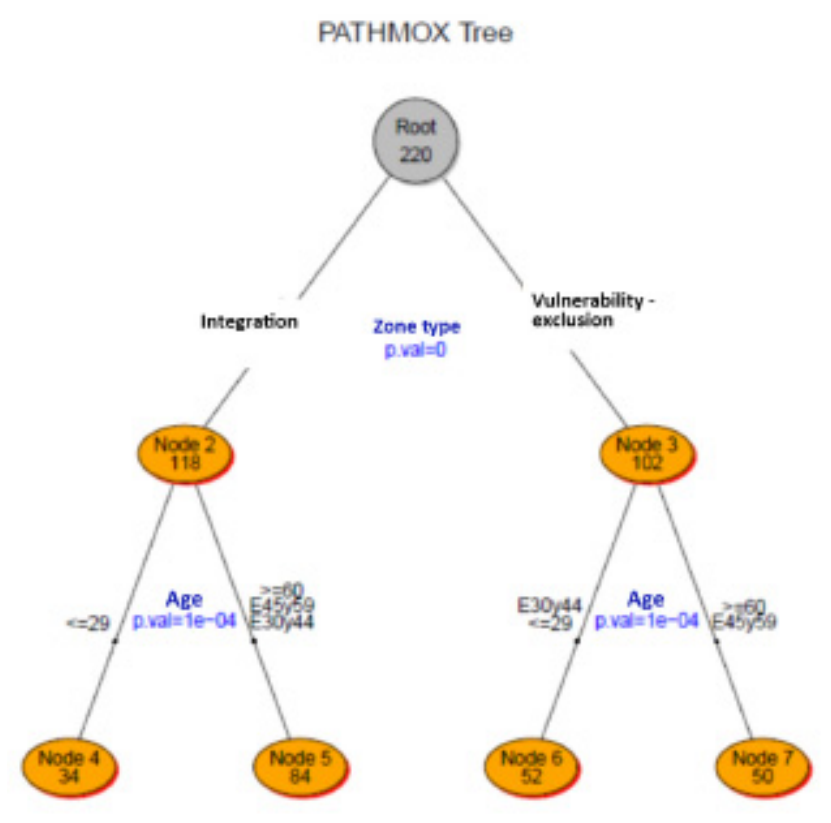

Figure 2. Decision tree based on the Pathmox algorithm 
Table 11. Paths coefficients of segments model

\begin{tabular}{|l|l|l|l|l|l|}
\hline Path & Root & $\begin{array}{l}\text { Urban } \\
\text { level=good and } \\
\text { age }<=29 \text { years }\end{array}$ & $\begin{array}{l}\text { Urban } \\
\text { level=good and } \\
\text { age }>=30 \text { years }\end{array}$ & $\begin{array}{l}\text { Urban level= } \\
\text { (Regular or bad) } \\
\text { and age }<=44 \\
\text { years }\end{array}$ & $\begin{array}{l}\text { Urban } \\
\text { (Regular or bad) } \\
\text { and age }>=45 \\
\text { years }\end{array}$ \\
\hline JobOpor->Consume & 0.551 & 0.572 & 0.501 & 0.547 & $\underline{0.672}$ \\
\hline Consume->Conservation & 0.366 & 0.266 & $\underline{0.448}$ & 0.349 & 0.230 \\
\hline Conservation->Self-Trasc & 0.611 & $\underline{0.716}$ & 0.539 & 0.569 & 0.594 \\
\hline Self-Trasc ->Open-Change & 0.575 & $\underline{0.659}$ & 0.548 & 0.521 & 0.523 \\
\hline Open-Change ->Self-Grow & 0.360 & 0.326 & 0.374 & $\underline{0.529}$ & 0.135 \\
\hline
\end{tabular}

Table 12. R square of segments model

\begin{tabular}{|c|c|c|c|c|c|}
\hline & Root & $\begin{array}{l}\text { Urban } \\
\text { level=good and } \\
\text { age }<=29 \text { years }\end{array}$ & $\begin{array}{l}\text { Urban } \\
\text { level=good and } \\
\text { age }>=30 \text { years }\end{array}$ & $\begin{array}{l}\text { Urban level= } \\
\text { (Regular or bad) } \\
\text { and age }<=44 \\
\text { years }\end{array}$ & $\begin{array}{l}\text { Urban level= } \\
\text { (Regular or bad) } \\
\text { and age }>=45 \\
\text { years }\end{array}$ \\
\hline JobOpor & 0.000 & 0.000 & 0.000 & 0.000 & 0.000 \\
\hline Consume & 0.303 & 0.327 & 0.251 & 0.299 & $\underline{0.452}$ \\
\hline Conservation & 0.134 & 0.071 & $\underline{0.200}$ & 0.122 & 0.053 \\
\hline Self-Trasc & 0.374 & $\underline{0.513}$ & 0.291 & 0.323 & 0.353 \\
\hline Open-Change & 0.331 & $\underline{0.434}$ & 0.300 & 0.272 & 0.274 \\
\hline Self-Growth & 0.130 & 0.106 & 0.140 & 0.280 & 0.018 \\
\hline
\end{tabular}

In the Figure 3, we compare the averages obtained in each one of the ten values for node 5 (individuals with a good urbanization level and age greater or equal to 30 years) with the remaining nodes. 


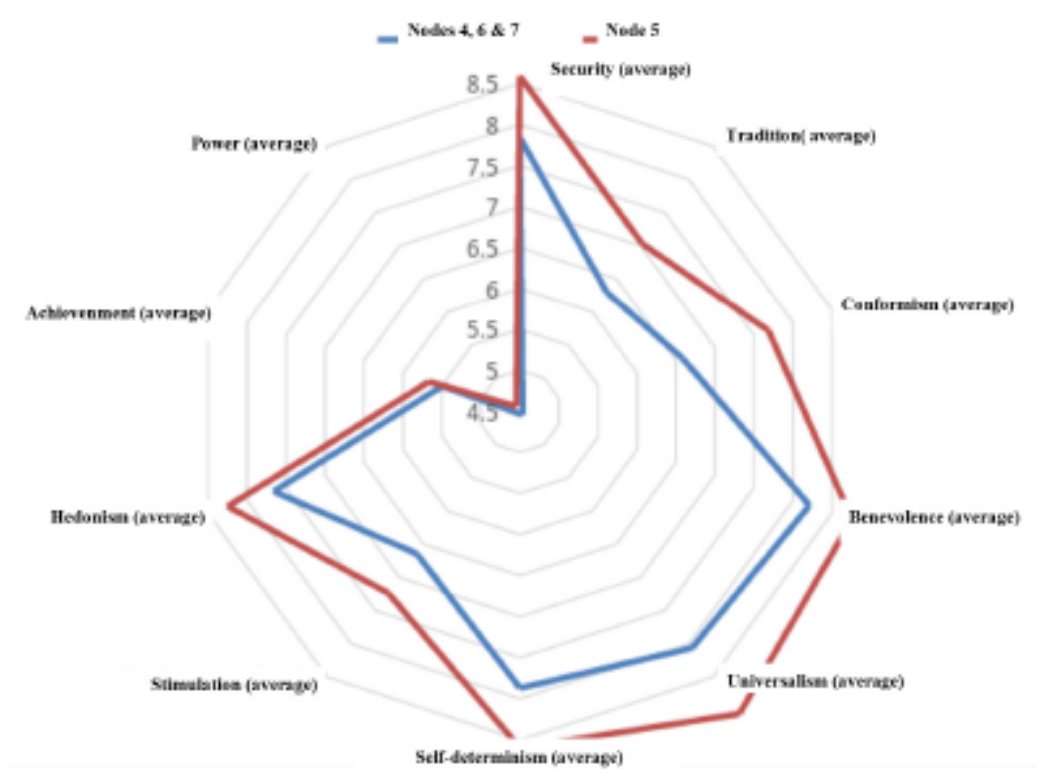

Figure 3. Comparative values between nodes 4-6-7 and node 5

The description of the value system becomes more clearly differentiated in more economically developed contexts that experience less institutional and ecological stress (Fischer et al., 2016). In economically poorer contexts, individuals have limited options and do not clearly differentiate between the motivational orientations inherent to values. It is only in an environmental context where people have opportunities to make decisions, in which a clear differentiation of values emerges in terms of underlying motivational structure (Fischer et al., 2016).

If the diagram shows it among the averages of the ten values segmented between nodes 5 and 7 , which represent the oldest individuals, regardless of the level of urbanization, and nodes 4 and 6 that represent the youngest, without considering the level of urbanization, we obtain the diagram of Figure 4. 


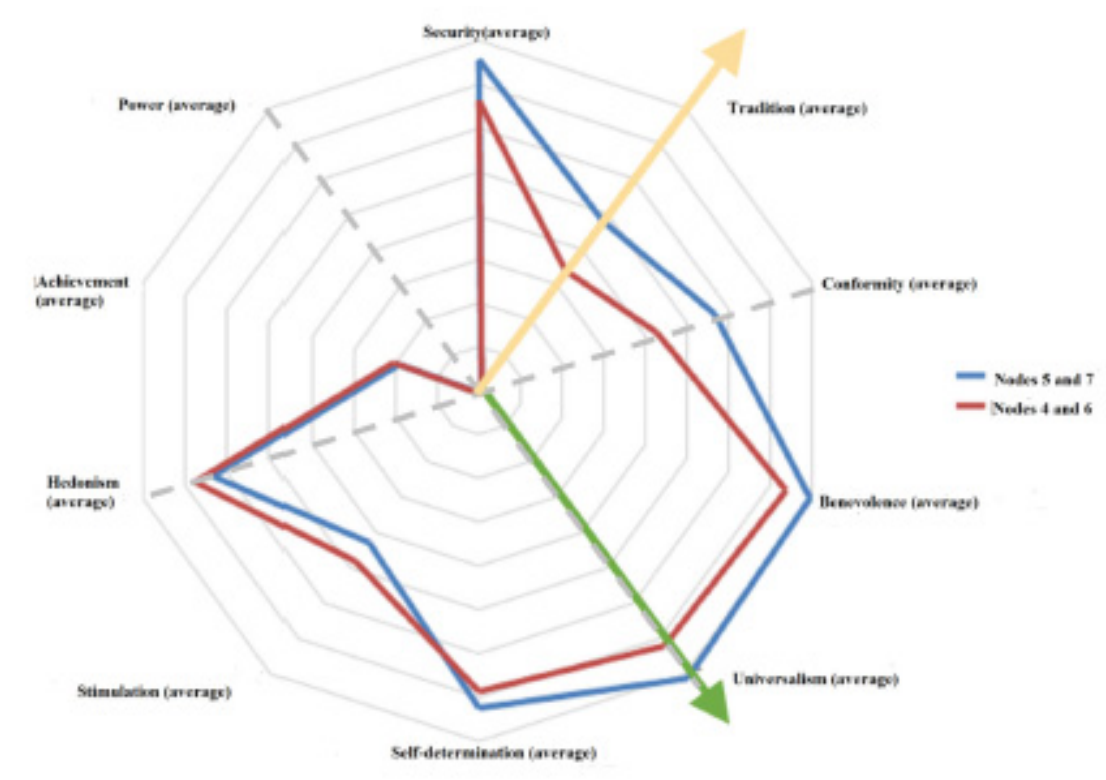

Figure 4. Comparative values between nodes 5-7 and 4-6

The main axes that organize this space are the Openness to change versus the values of Conservatism (those that emphasize the search for self-directed, autonomous and hedonistic values versus those that emphasize the values that promote stability and Maintenance of the social and cultural system) and Self-transcendence in relation to the values of Self-growth (distinctive values that emphasize the well-being of others close and far away and the environment against exploitation and domination of opportunities, resources and people, to improve one's position and status in social consideration) (Fischer \& Boer, 2016). Nodes 5 and 7, which target are older individuals, tend to develop protection areas, while nodes 4 and 6 composed of younger individuals tend, as the arrow shows, to venture into Emancipation and Growth zones.

\section{Discussion}

The beliefs are organized hierarchically (Lindenberg, 1996; Maslow, 1954; Rockeah, 1973) and serve as guides for human behavior. At the base, there is the satisfaction of the needs of self-protection and the physiological ones, such as: hunger, thirst and sleep (see figure 5). It is an organized system of needs (Maslow, 1954), acquired in the processes of primary (family and peer group) and secondary (schools and other institutions) socialization. The higher levels belong to the personal priority values that result from the adaptation to life experiences, expansion, personal fulfillment, through Openness to Change and Self Growth (Hierarchies exist, for example, in the development of empathy in mammals if we conceive it from several layers). 


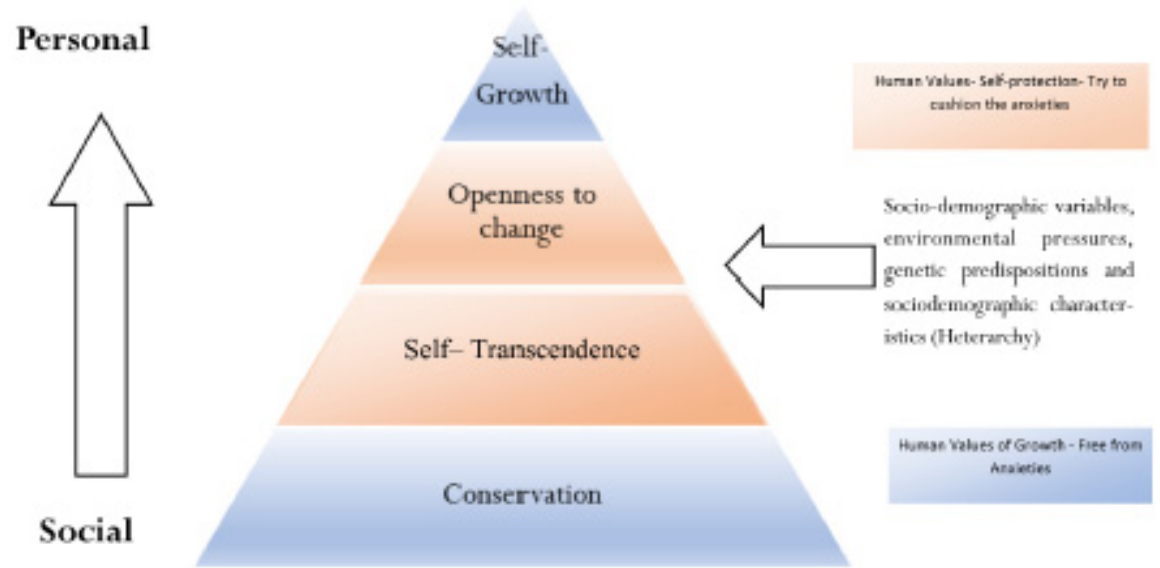

Figure 5. Human Values conceived as a nested scalar hierarchy with pyramidal structure

At the base of the pyramid, values are related to social aspects, serving the interests of the whole community. At the top of the pyramid, values are individualistic, prioritizing aspects of personal development and success

The values form a continuum of related motivations, any level can affect any other, although the position of an element in a hierarchical structure is invariant (nested scalar hierarchy). The nature of this continuum is seen in the emphasis of shared motivation on adjacent values (Schwartz, 1994). Once the higher order processes exist they modify the base processes. The process of higher order is the accumulated prestige or power acquired through the recognition of the agents of the social space of action and influence in which certain social relations converge. (Bourdieu \& Thompson, 1991).

The perception of the generation and distribution of resources of the habitat and the other cognitive niches, in present and future time, influence in the value system, as to the relations and their force, so they are ordered and recategorized by the change of conditions (Chiao \& Blizinsky, 2010). The decisions are based on the context assessment. They are promulgated by the system, on a broad scale of semiotic freedom. Therefore, the possibility of anomalies exists in the options of the repertoire, so that these options are not classified "only" in a hierarchical way. It is a heterarchy of values depending on the context and can vary from one situation to another, without contradicting a hierarchical structure, but using several. It is a potential command principle in which information replaces authority. The change of values (sometimes contradictory) leads to a continuous rearrangement of priorities (McCulloch, 1945; Crumley, 1987, 1995, 2007; Newell et al., 2005), while it challenges order as predictability. It is a vast periodic table of ethics, there is no single monolithic moral sense or a simple combination of desires and beliefs (Curry, 2016). 


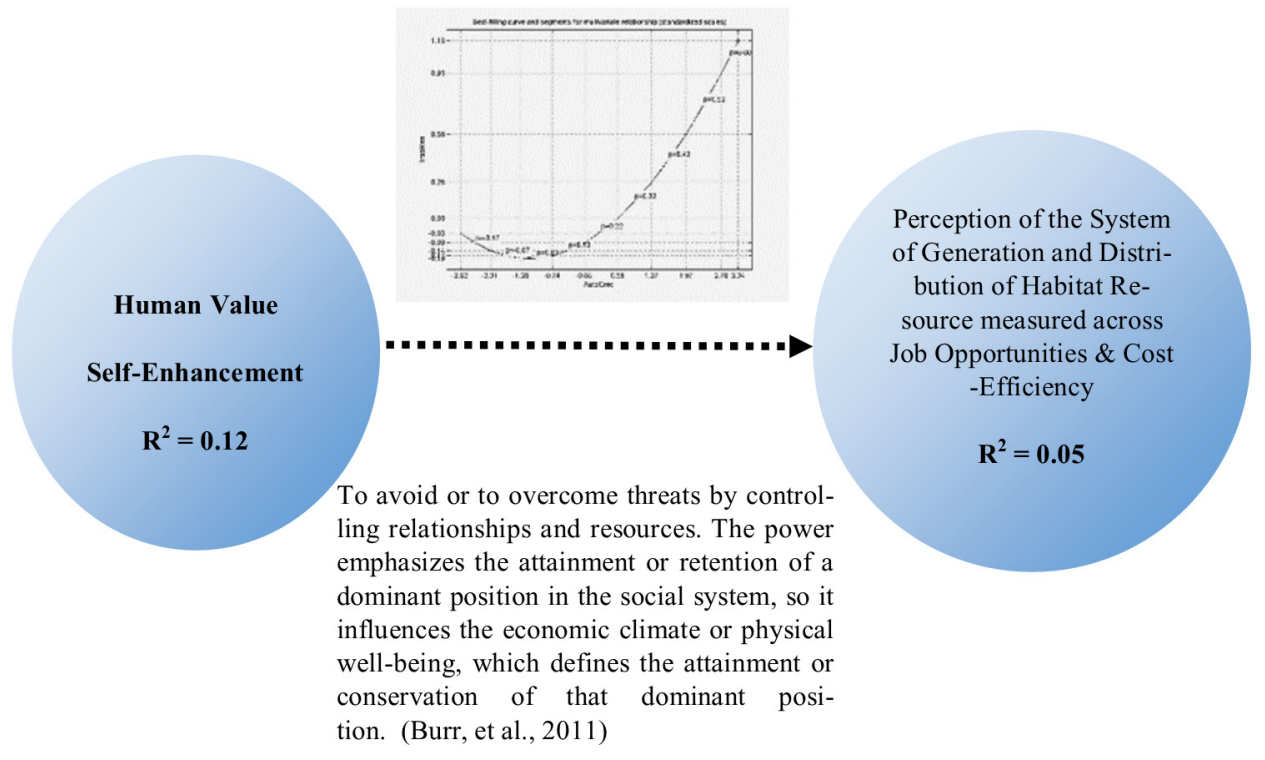

Figure 6. Relationship between the Human Value Auto-Enhancement and Job Opportunities / Cost-Efficiency

When we calculated the path coefficient between the evaluation of the importance of the human value Self-enhancement and Perception of the System of Generation and Distribution of the Habitat Resource a value of 0.22 is obtained with $p<0.01$ (see figure 6). However, the structural equation model based on partial least squares does not allow cyclical relationships as would occur if this relationship is added. Given this situation, we propose:

a) that the construct Perception of the System Resource Generation and Distribution, measured at time $t=1$ and later $t=t+1$. This allows a latent variable "Prior evaluation of Generation and Distribution of Habitat Resources" $(t=1)$ becomes an independent variable of the variable "Perception of Consumption / Esthetics \& Social Cohesion" $(t=1)$ and the construct "Later evaluation of Generation and Distribution of Habitat Resources" $(t=t+1)$ is a variable dependent on the perception of "Human Value Auto-growth" $(t=1)$.

b) A recursive system that can be represented by a dynamics model system, cyclical, with socio-demographic variables (age and educational level). It is a way of representing historical knowledge, considering the human value Self-growth as an endogenous variable (see Figure 7). 


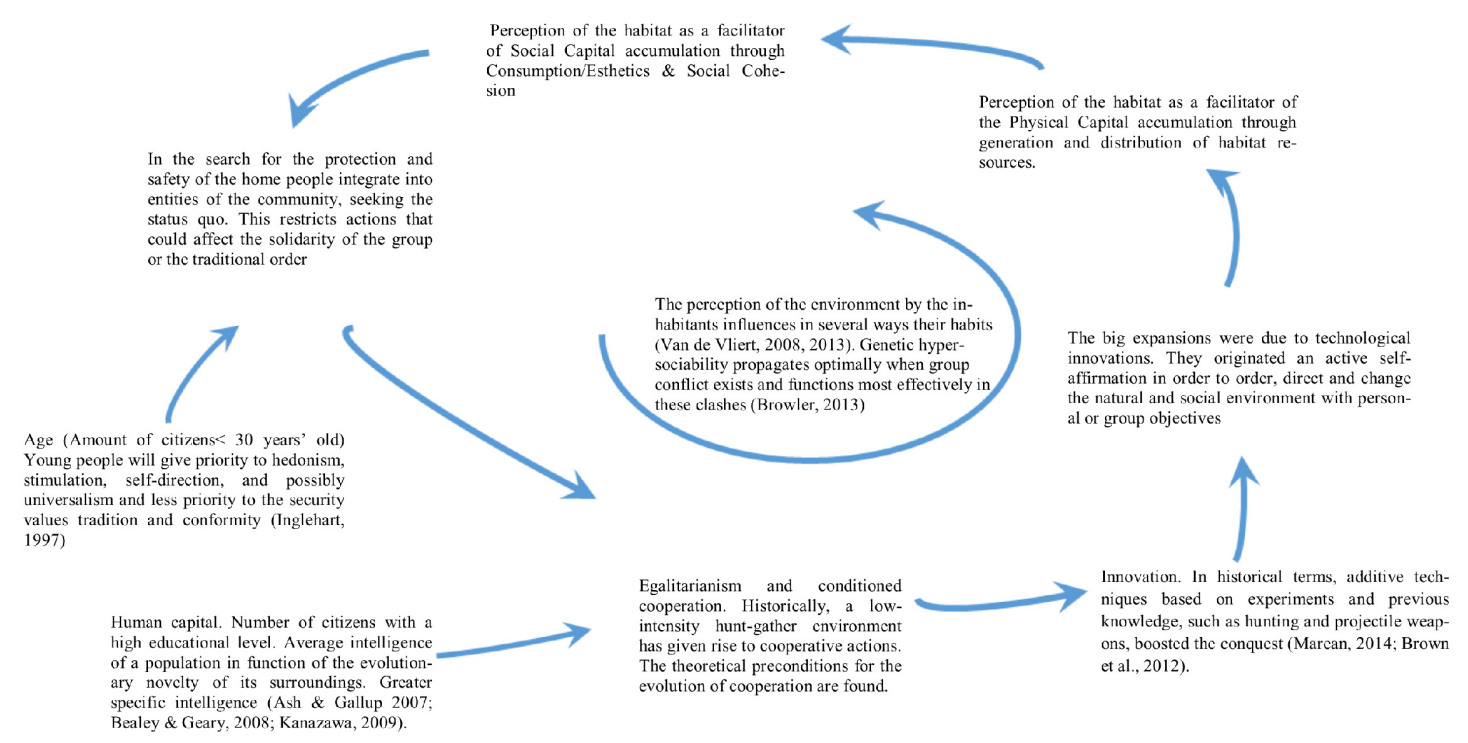

Figure 7. Recursive conceptualization represented by a Dynamic System model with positive / negative feedback

From the theoretical point of view, we can surmise that the domain is the cultural response that promotes an active self-affirmation to dominate, direct and change the natural and social environment with personal or group goals. Hierarchical systems tend to social order, mediated by environmental conditions as facilitators of the accumulation of physical and social capital. (Vauclair et al., 2011; Gomez Fonseca, 2004; Boer \& Fischer, 2013; Schwartz, 2006). Power aims status, reputation and prestige, along with control or dominance over people and resources through self-growth related to the perception of Physical Fitness from the evaluation of space climate-economic of the system of generation and distribution of Habitat resources. A degree of differentiation of status is necessary to run social institutions (de Waal, 1989, 1992; de Waal et al., 1993), and the same concept that the individual needs of mastery and control (Korman, 1974) are enclosed with authority, wealth and social recognition. 


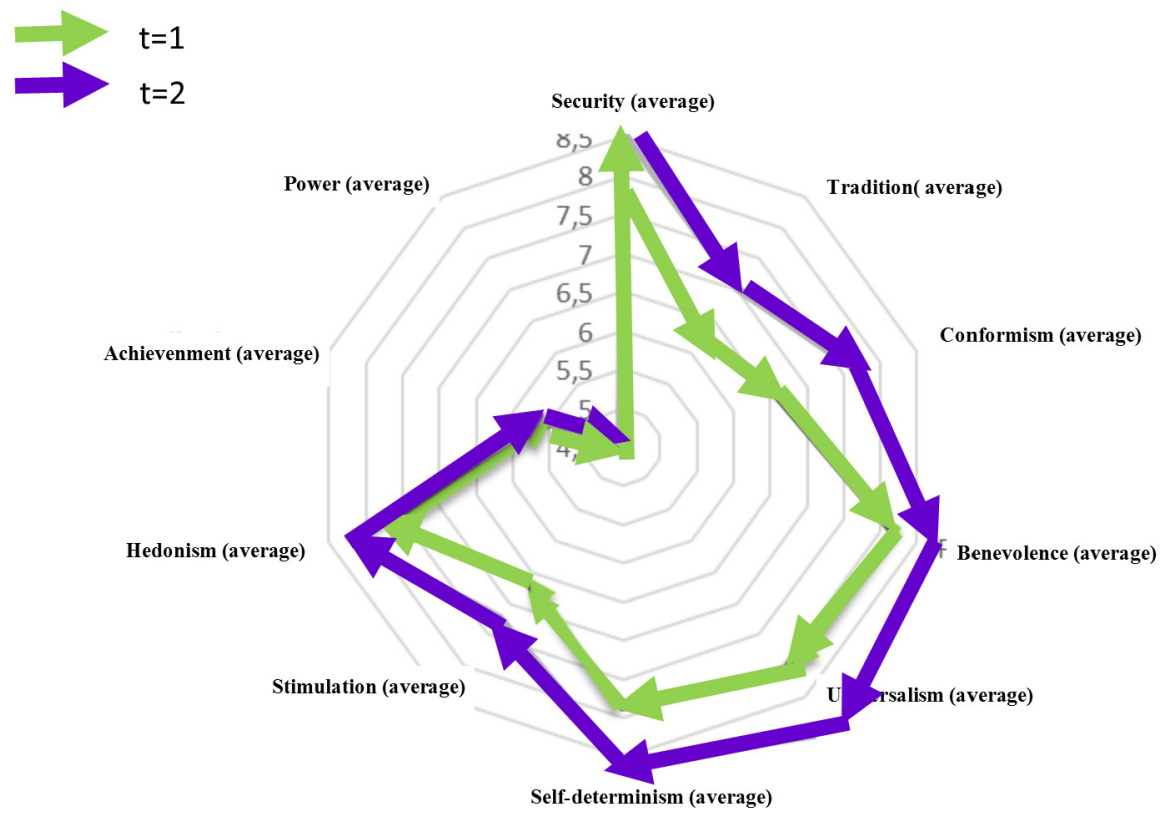

Figure 8 . The trajectory of the change of values in citizens with a higher level of urbanization and senior age

If it is possible to find the appropriate segmentation variables of the model, we can arrive at similar circuits (more than two) of the figure 3. This can be interpreted from a historical route, represented by a spider web in an unstable circular graph, that describes the trajectory of the change of values in citizens with a higher level of urbanization and senior age (see Figure 8).

This hierarchy, historically nested, accounts for a spiral of development that generates a monodromy of human values (From a historical point of view, the war, the commerce and the religion did not cease to exist but always acquired new degrees of refinement -conceptualized through the development spiral). When the historical trajectory "returns" to the same axis of a certain Human Value, the "end" will not be the same with which it was started. Something changes when a complete return of the stock structure is temporarily made. In addition to the obvious, time measured in months or years, we postulate that other attributes have also undergone changes, including the symbolic capital through which each Human Value is explained, applied or described in different cognitive niches. As we mentioned, to interpret each cycle as a historical trajectory we recognize a monodromy. It varies a series of intangible properties inherent to the subject that can only exist insofar as they are recognized by others, and by means of which each Human Value is recognized by other members of the belonging group (Sztompka, 1999; Cohen \& Prusak, 2001). Methodologically the symbolic capital may be implicit in the measuring instrument, through the type of stimuli that are used to measure each human value.

The innate desires for freedom of choice and equal opportunities are limited if people do not have sufficient resources to improve their living conditions. We conjecture that each cognitive niche represented by a spiral cycle indicates a better use of the potential sources of 
available social capital in certain human groups (Kanazawa, 2009).

This leads to a differential of symbolic capital that influences the selection of means to achieve the goal of status. This increase of symbolic capital is related to the power and the type of intelligence that predominates, related to the class ethos and to the possibility of inheritance of cognitive abilities (Bourdieu, 1998; Kanazawa, 2007; Reay et al., 2005; Ash \& Gallup, 2007; Kanazawa, 2008; Bailey \& Geary, 2009; Clark, 2009, Martin, 2010). In some cognitive niches the needs of economic well-being have been surpassed, and post-materialistic values of self-transcendence predominate (Inglehart, 1977).

\section{References}

Anderson, J. C., \& Gerbing, D. W. (1988). Structural equation modeling in practice: A review and recommended two-step approach. Psychological Bulletin, 103(3), 411-423. https://doi.org/10.1037/0033-2909.103.3.411

Bandura, A. (1977). Self-efficacy: Toward a unifying theory of behavioral change. Psychological Review, 84, 191-215. https://doi.org/10.1037/0033-295X.84.2.191

Barclay, D., Higgins, C., \& Thompson, R. (1995). The Partial Least Squares (PLS) Approach to Causal Modelling: Personal Computer Adoption and Use as an Illustration, Technology Studies, Special Issue on Research Methodology, 2(2), 285-309.

Boer, D., \& Fischer, R. (2013). How and When Do Personal Values Guide Our Attitudes and Sociality? Explaining Cross-Cultural Variability in Attitude-Value Linkages. Psychological Bulletin. https://doi.org/10.1037/a0031347

Bourdieu, P. (1998). The state nobility: Elite schools in the field of power. Stanford University Press.

Bourdieu, P., \& Thompson, J. B. (1991). Language and symbolic power. Harvard University Press.

Bourdieu, P. (1984). Distinction. A social critique of the judgment of taste, Cambridge, Mass., Harvard University Press.

Bourdieu, P., \& Passeron, J.-C. (1973), Cultural Reproduction and Social Reproduction. In R. Brown (Ed.), Knowledge, Education and Cultural Change (pp. 71-112), London: Tavistock.

Bowles, S., \& Gintid, H. (2013). A Cooperative Species: Human Reciprocity and its Evolution. Princeton University Press.

Brown, K. S., Marean, C. W., Jacobs, Z., Schoville, B. J., Oestmo, S., Fischer, E. C., \& Matthews, T. (2012). An early and enduring advanced technology originating 71,000 years ago, in South Africa. Nature, 491, 7425, 590-593. https://doi.org/10.1038/nature11660

Burkart, J. M., Hrdy, S. B., \& Van Schaik, C. P. (2009). Cooperative breeding and human cognitive evolution. Evolutionary Anthropology: Issues, News, and Reviews, 18(5), 175-186. https://doi.org/10.1002/evan.20222 
Cavalli-Sforza, L. L. (1997). Genes, peoples, and languages. Proceedings of the National Academy of Sciences of the United States of America, 94, 15, 7719-24. https://doi.org/10.1073/pnas.94.15.7719

Chiao, J. Y., \& Blizinsky, K. D. (2010). Culture-gene coevolution of individualism-collectivism and the serotonin transporter gene. Proceedings of the Royal Society of London B: Biological Sciences, 277, 1681, 529-537. https://doi.org/10.1098/rspb.2009.1650

Chin, W. W., Marcolin, B. L., \& Newsted, P. R. (2003). A partial least squares latent variable modeling approach for measuring interaction effects: results from a Monte Carlo simulation study and an electronic mail emotion/ adoption study. Information Systems Research, 14(2), 189-217. https://doi.org/10.1287/isre.14.2.189.16018

Churchland, P. S. (2011). Braintrust: What neuroscience tells us about morality. Princeton University Press. https://doi.org/10.1515/9781400838080

Clark, G. (2009). Clark, G. (2009). The Domestication of Man: The Social Implications of Darwin. Artefactos, 2(1), 64.

Cohen, D., \& Prusak, L. (2001). In good company: How social capital makes organizations work. Harvard Business Press. https://doi.org/10.1145/358974.358979

Crumley, C. L. (1987). Historical ecology. Regional Dynamics: Burgundian Landscapes in Historical Perspective, 237-264.

Crumley, C. L. (1995). Heterarchy and the analysis of complex societies. Archeological Papers of the American Anthropological Association, 6(1), 1-5. https://doi.org/10.1525/ap3a.1995.6.1.1

Crumley, C. L. (2007). Historical ecology: integrated thinking at multiple temporal and spatial scales. The World System and the Earth System: Global Socioenvironmental Change and Sustainability Since the Neolithic, Left Coast Press, Walnut Creek, CA, 15-28.

Curry, O. S. (2016) Morality as Cooperation: A Problem-Centred Approach. In T. K. Shackelford, \& R. D. Hansen (Eds.), The Evolution of Morality (pp. 27-51). Springer International Publishing. https://doi.org/10.1007/978-3-319-19671-8_2

de Waal, F. B. M. (1989). Food sharing and reciprocal obligations among chimpanzees. Journal of Human Evolution, 18, 433-459. https://doi.org/10.1016/0047-2484(89)90074-2

de Waal, F. B. M. (1992). Appeasement, celebration, and food sharing in the two Pan species. In T. Nishida, W. C. McGrew, \& P. Marler (Eds.), Topics in primatology: Human origins, (pp. 37-50). Tokyo: University of Tokyo Press.

de Waal, F. B. M., Luttrell, L. M., \& Canfield, M. E. (1993). Preliminary data on voluntary food sharing in brown capuchin monkeys. American Journal of Primatology, 29, 73-78. https://doi.org/10.1002/ajp.1350290108

Dutton, D. (2003). Aesthetics and Evolutionary Psychology. In J. Levinson (Ed.) The Oxford 
Handbook of Aesthetics (pp. 693-705). Oxford University Press, Oxford.

Fischer, R., Vauclair C-M., Fontaine, J. R. J., \& Schwartz, S. H. (2010). Are individual-level and country-level value structures different? Testing Hofstede's legacy with the Schwartz Value Survey. Journal of Cross Cultural Psychology, 41(2), 135-151. https://doi.org/10.1177/0022022109354377

Fischer, R. (2012). Value isomorphism in the European Social Survey: exploration of meaning shifts in values across levels. Journal of Cross Cultural Psychology, 43(6), 883-898. https://doi.org/10.1177/0022022111413276

Fischer, R. (2013). What values can (and cannot) tell us about individuals, society and culture. In M. Gelfand, C.Chiu \& Y.Hong (Eds) Advances in Culture and Psychology, 4, 218-272. https://doi.org/10.1093/acprof:osobl/9780199336715.003.0005

Fischer, R., \& Boer, D. (2016). Values: the dynamic nexus between biology, ecology and $\begin{array}{lllll}\text { culture, } \quad \text { Current in } \quad \text { Psychology, } & \text { 8, } & \text { 155-160. }\end{array}$ https://doi.org/10.1016/j.copsyc.2015.12.009

Gomez Fonseca, M. Á. (2004). Reflexiones sobre el concepto de embeddedness. Polis: Investigación y Análisis Sociopolítico y Psicosocial, 2, 145-164.

Fornell, C., \& Larcker, D. F. (1981). Evaluating Structural Equation Models with Unobservable Variables and Measurement Error, Journal of Marketing Research, 18, 39-50. https://doi.org/10.2307/3150980

Glaeser, E. L., \& Gottlieb, J. D. (2006). Urban resurgence and the consumer city. Urban studies, 43(8), 1275-1299. https://doi.org/10.1080/00420980600775683

Glaeser, E. L., Kolko, J., \& Saiz, A. (2000). Consumer city. Journal of Economic Geography, l(1), 27-50. https://doi.org/10.1093/jeg/1.1.27

Goetze, D. B., \& James, P. (2004). Evolutionary psychology and the explanation of ethnic $\begin{array}{llll}\text { phenomena. } \quad \text { Evolutionary } & \text { Psychology, } & 2, & 142-159 .\end{array}$ https://doi.org/10.1177/147470490400200120

Hair, J. F., Black, W. C., Babin, B. J., \& Anderson, R. E. (2009). Multivariate data analysis. Upper Saddle River, NJ: Prentice Hall. https://doi.org/10.1016/j.csda.2008.11.030

Hamilton W. D. (1964a). The Genetical Evolution of Social Behavior I. Journal of Theoretical Biology, 7, 1-16. https://doi.org/10.1016/0022-5193(64)90039-6

Hamilton W. D. (1964b). The Genetical Evolution of Social Behavior II. Journal of Theoretical Biology, 7, 17-52. https://doi.org/10.1016/0022-5193(64)90039-6

Heffetz, O., \& Frank, R. H. (2008). Preferences for status: Evidence and economic implications. In J. Benhabib, A. Bisin, \& M. Jackson (Eds.), Handbook of Social Economics, $1,69-91$.

House, R. J., Hanges, P. J., Javidan, M., Dorfman, P. W., \& Gupta, V. (2004). Culture, 
Leadership and Organizations: The GLOBE Study of 62 Societies. Sage Publications.

Inglehart R. (1977). The silent revolution: Changing values and political styles among Western publics. Princeton, NJ: Princeton University Press.

Inglehart, R., \& Baker, W. E. (2000). Modernization, cultural change, and the persistence of traditional values. American Sociological Review, 65, 19-51. https://doi.org/10.2307/2657288

Kanazawa, S. (2010). Why liberals and atheists are more intelligent. Social Psychology Quarterly, 73, 1. https://doi.org/10.1177/0190272510361602

Kanazawa, S., \& Savage, J. (2009). An evolutionary psychological perspective on social $\begin{array}{llll}\text { capital. Journal of Economic Psychology, 30(6), 873-883. } & \text {. }\end{array}$ https://doi.org/10.1016/j.joep.2009.08.002

Korman, A. (1974). The Psychology of Motivation. Prentice-Hall.

Lindenberg, S. (1996). Continuities in the 10 Theory of Social Production Functions. Verklarende sociologie: Opstellen voor Reinhart Wippler, 169-184.

Marean, C. W. (2014). The origins and significance of coastal resource use in Africa and Western Eurasia. Journal of human evolution, 77, 17-40. https://doi.org/10.1016/j.jhevol.2014.02.025

Maslow, A. H. (1962). Towards a psychology of being. Princeton: D. Van Nostrand Company. https://doi.org/10.1037/10793-000

Martin, N. D. (2010). Social Class and Elite University Education: A Bourdieusian Analysis (Doctoral dissertation, Duke University).

Mazur, A. (2005). Biosociology of Dominance and deference. New York: Rowman and Littlefield.

McCulloch, W. S. (1945). A heterarchy of values determined by the topology of nervous nets. The bulletin of mathematical biophysics, 7(2), 89-93. https://doi.org/10.1007/BF02478457

Morenoff, J. D., Sampson, R. J., Raudenbush, S. W. (2001). Neighborhood Inequality, Collective Efficacy, and the Spatial Dynamics of Urban Violence, Criminology, 39, 517-558. https://doi.org/10.1111/j.1745-9125.2001.tb00932.x

Newell, B., Crumley, C. L., Hassan, N., Lambin, E. F., Pahl-Wostl, C., Underdal, A., \& Wasson, R. (2005). A conceptual template for integrative human-environment research. Global Environmental Change, 299-307. https://doi.org/10.1016/j.gloenvcha.2005.06.003

Newson, L., Richerson, P., \& Boyd, R. (2005). Cultural Evolution and the Shaping of Cultural Diversity, Handbook of Cultural Psychology.

Nigro, H. O., \& González Císaro, S. E. (2016). The citizen satisfaction index: Adapting the model in Argentine cities. Cities, 56, 85-90. https://doi.org/10.1016/j.cities.2016.03.010 
O'Brien, D. (2012). Getting to Know your Neighbors: Incorporating Evolutionary Psychology into Urban Research-Policy collaborations. Journal of Social, Evolutionary, and Cultural Psychology, 6(3), 329-343. https://doi.org/10.1037/h0099248

Pinker, S. (2003). La tabla rasa. La negación moderna de la naturaleza humana. Paidós Ibérica.

Queller, D. C. (1995). The measurement and meaning of inclusive fitness. Animal Behaviour, 51(1), 229-232. https://doi.org/10.1006/anbe.1996.0020

Reay, D., David, M. E., \& Ball, S. J. (2005). Degrees of choice: Class, race, gender and higher education. Trentham Books.

Rokeach, M. (1973). The nature of human values. N.York: Free Press.

Schwartz, S. H. (1992). Universals in the content and structure of values: Theory and empirical tests in 20 countries. Advances in Experimental Social Psychology, 25, 1-65. https://doi.org/10.1016/S0065-2601(08)60281-6

Schwartz, S. H. (1994). Are there universal aspects in the structure and contents of human $\begin{array}{lllll}\text { values? } & \text { Journal } & \text { of } & \text { social }\end{array}$ https://doi.org/10.1111/j.1540-4560.1994.tb01196.x

Schwartz, S. H., \& Bardi, A. (2001). Value hierarchies across cultures: Taking a similarities perspective. Journal of Cross Cultural Psychology, 32, 268-290. https://doi.org/10.1177/0022022101032003002

Schwartz, S. H., \& Bilsky, W. (1987). Toward a universal psychological structure of human values. Journal of Personality and Social Psychology, 53, 550-562. https://doi.org/10.1037/0022-3514.53.3.550

Schwartz, S. H. (2006). Les valeurs de base de la personne: Théorie, mesures et applications [Basic human values: Theory, measurement, and applications]. Revue Française de Sociologie, 47, 249-288. https://doi.org/10.3917/rfs.474.0929

Schwartz, S. H., Cieciuch, J., Vecchione, M., Davidov, E., Fischer, R., Beierlein, C., ... Konty, M. (2012). Refining the theory of basic individual values. Journal of Personality and Social Psychology, 103(4), 663-688. https://doi.org/10.1037/a0029393

Sztompka, P. (1999). Trust: A sociological theory. Cambridge University Press.

Trivers, R. L. (1972). Parental investment and sexual selection. In B. Campbell (Ed.), Sexual selection and the descent of man (pp. 1871-1971, 136-179). Chicago: Aldine.

Van de Vliert, E. (2008). Climate Affluence and Culture. Cambridge, University Press. https://doi.org/10.1017/cbo9780511575297

Van de Vliert, E. (2013). Climato-economic habitats support patterns of human needs, stresses, and freedoms. Behavioral and Brain Sciences Journal, 1-16. https://doi.org/10.1017/s0140525x12002828 


\section{Macrothink}

Vauclair, C. M., Hanke, K., Fischer, R., \& Fontaine, J. (2011). The structure of human values at the culture level: A meta-analytical replication of Schwartz's value orientations using the Rokeach Value Survey. Journal of Cross-Cultural Psychology, 42(2), 186-205. https://doi.org/10.1177/0022022110396864

Welzel, C. (2014). Freedom Rising: Human Empowerment and The Quest for Emancipation. Cambridge University Press.

Wold, H. (1979). Model Construction and Evaluation when Theoretical Knowledge Is Scarce: An Example of the Use of Partial Least Squares. Cahiers du Département D'Économétrie. Genève: Faculté des Sciences Économiques et Sociales, Université de Genève

Kock, N. (2013). WarpPLS 4.0 User Manual, ScriptWarp Systems, Laredo, Texas USA

Zenker, S., \& Beckmann, S. C. (2013). My place is not your place-Different place brand knowledge by different target groups. Journal of Place Management and Development, 6, 6-17. https://doi.org/10.1108/17538331311306078

Zenker, S., \& Gollan, T. (2010). Development and implementation of the resident migration scale (ReMiS): Measuring success in place marketing. In E. H. Witte, \& T. Gollan (Eds.), Sozialpsychologie und Okonomie, 156-172. Lengerich: Pabst Verlag. 1 http://dx.doi.org/0.1057/pb.2011.5

Zenker, S., Gollan, T., \& Quaquebeke, N. (2014). Using polynomial regression analysis and response surface methodology to make a stronger case for value congruence in place marketing. Psychology \& Marketing, 31, 3, 184-202. http://dx.doi.org/ 10.1002/mar.20686

Zenker, S., Petersen, S., \& Aholt, A. (2013). The Citizen Satisfaction Index (CSI): Evidence for a four-basic factor model in a German sample. Cities, 31, 156-164. http://doi.org/10.1016/j.cities.2012.02.006

\section{Copyright Disclaimer}

Copyright for this article is retained by the author(s), with first publication rights granted to the journal.

This is an open-access article distributed under the terms and conditions of the Creative Commons Attribution license (http://creativecommons.org/licenses/by/3.0/). 